\title{
Magmatic Material in Sandstone Shows Prospects for New Diamond Deposits within the Northern East European Platform
}

\author{
Elena Agasheva
}

Citation: Agasheva, E. Magmatic Material in Sandstone Shows Prospects for New Diamond Deposits within the Northern East European Platform. Minerals 2021, 11, 339. https://doi.org/10.3390/min11040339

Academic Editor: David Phillips

Received: 4 February 2021

Accepted: 23 March 2021

Published: 25 March 2021

Publisher's Note: MDPI stays neutral with regard to jurisdictional claims in published maps and institutional affiliations.

Copyright: (C) 2021 by the author. Licensee MDPI, Basel, Switzerland. This article is an open access article distributed under the terms and conditions of the Creative Commons Attribution (CC BY) license (https:// creativecommons.org/licenses/by/ $4.0 /)$.
Sobolev Institute of Geology and Mineralogy, Siberian Branch of the Russian Academy of Sciences, 630090 Novosibirsk, Russia; helenashchukina@gmail.com

\begin{abstract}
A detailed study of sandstones recovered from the upper part of the recently discovered KL-01 magmatic pipe in the southern part of the Arkhangelsk diamondiferous province (ADP), containing magmatic material and rare kimberlite indicator minerals, is presented in this paper. Results are compared to the composition of crater samples of the highly diamondiferous Vladimir Grib kimberlite pipe and several poorly to non-diamondiferous ADP pipes. To identify the type of magmatic material admixture, a model of binary mixing between country Vendian sandstones and typical ADP magmatic rocks based on correlations of $\mathrm{La} / \mathrm{Yb}$ and $\mathrm{Zr} / \mathrm{Nb}$ ratios and $\mathrm{Ni}$ contents is proposed. The modeling results show that the type of magmatic component in the KL-01 samples can be identified as kimberlite, with a maximum admixture of $20 \mathrm{vol} \%$. Kimberlite indicator mineral geochemistry did not exclude the interpretation that the composition, structure, thermal state and metasomatic enrichment of the lithospheric mantle sampled by the KL-01 pipe were suitable for the formation and preservation of diamonds. The lower boundary of the sampled lithospheric mantle could be in the depth range of $175-190 \mathrm{~km}$, with a diamond window width of $55-70 \mathrm{~km}$. Thus, the sandstones could represent the upper level of the crater of a new kimberlite pipe.
\end{abstract}

Keywords: Kola craton; diamond exploration; kimberlite indicator mineral; pyrope geochemistry; lithospheric mantle; saponite

\section{Introduction}

The Arkhangelsk region (with an area of $\sim 590,000 \mathrm{~km}^{2}$ ), located in the northern portion of the East European Platform (Figure 1), is one of the major industrial diamondiferous areas in Russia. To date, 100 magmatic bodies of mafic and ultramafic compositions are known within the northern part of the region and form the Arkhangelsk diamondiferous province (ADP, with an area of $\sim 19,000 \mathrm{~km}^{2}$ [1]). Two major diamond deposits are found within the ADP: the Lomonosov and Grib mines [2]. Since the discovery of the V. Grib kimberlite pipe in 1996, no new diamondiferous kimberlites have been identified either within the ADP or within the region. However, recent studies [1,3] show that several areas, both within the ADP and outside it, have high potential to host local diamondiferous kimberlite sources.

Most of the ADP magmatic bodies were discovered during the 1970s and 1980s, a period of intense geological prospecting works for diamonds, which were motivated by the discovery of the first diamondiferous kimberlites in Yakutia (Siberian craton, NE Russia). All the ADP magmatic bodies were discovered through aeromagnetic surveys, which were preceded by detailed geological surveying and use of the indicator mineral method [4]. Due to the sedimentary cover over the pipes, with a minimum thickness of 30-50 $\mathrm{m}$ in the western ADP and a maximum of 150-200 $\mathrm{m}$ in the eastern ADP, the application of the indicator mineral method alone cannot provide information about the source location.

Any prospective area within the ADP identified by mineral indicator sampling should be covered by high-resolution (1:10000-1:5000) aeromagnetic surveys, followed by detailed ground magnetic surveys, which can identify local geophysical or "pipe-like" anomalies. These anomalies are potential kimberlite targets and should be investigated further by 
drilling. First, prospecting for kimberlites using local magnetic anomalies (LMAs) yielded fairly good results, and approximately $10 \%$ of drilled targets yielded pipes [5]. For example, test drilling of 58 pipe-like anomalies within the ADP Verhotina field resulted in the discovery of eight magmatic pipes, including six olivine melilitites and two kimberlites [4]. However, the majority of pipe-like anomalies identified through aeromagnetic surveys in the 1970s-1990s have already been tested [6]. Therefore, new detailed prospecting activity within this region is required.

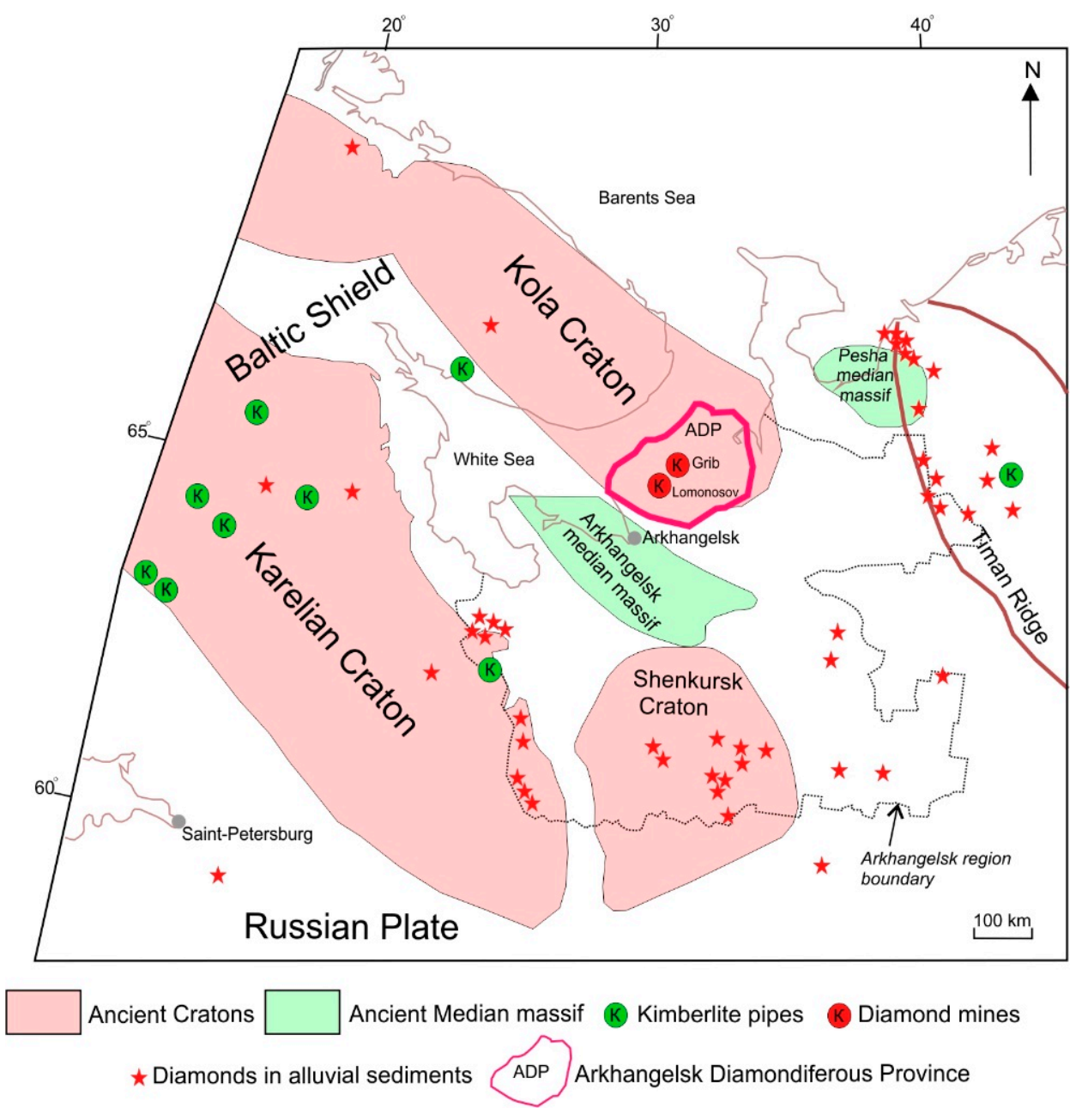

Figure 1. Tectonic scheme of the northern East European platform, adapted from [1].

However, the interpretation of geophysical data is complicated by the fact that the physical properties of the ADP kimberlites (density, electrical conductivity and magnetization) differ little from those of the country rocks [4,7]; i.e., not every pipe-like anomaly is a real magmatic pipe. An additional problem is that the center of the pipe-like anomaly may not match the geometric center of the real pipe. This problem could imply that some test drillings during the 1970s-1990s were outside of pipes and a certain number of magmatic bodies were missed. For example, the center of the LMA is displaced from the geometric center of the V. Grib pipe by $200 \mathrm{~m}$ to the east [4]. The first test drilling in the area of the V. Grib pipe was in 1986 (now, it is clearly known to have been outside of the pipe), whereas kimberlite was discovered only in 1996 [4]. Another problem for potential pipe identification is that the majority of the ADP magmatic bodies include craters with widths varying from $20-40 \mathrm{~m}$ to $200-300 \mathrm{~m}$. The craters consist of various volcaniclastic (tuff, tuff breccia, xeno-tuff breccia); volcaniclastic-sedimentary (sandstone with magmatic material); and sedimentary (sandstone) rocks. The upper levels of the craters can be represented by reddish-brown sandstones without any magmatic material, which are similar to the 
country rocks (Vendian sandstones). The thickness of such layers can reach $100 \mathrm{~m}$, and in drilling, they can be identified as country rocks. If so, drilling is ended, justified by the assumption that the borehole is outside the pipe. Dozens of drilling programs are known to have been stopped for this reason. Thus, numerous and detailed drilling steps are required for successful prospecting, which significantly increases the cost of such work, especially considering the specific climate of the region and the lack of infrastructure.

However, in 2017, after 2 years of intensive sampling and geophysical work, the Proex Service geology team localized the " $\mathrm{K}$ " area for diamond exploration in the southern part of the ADP. The interpretation of the morphology and geochemistry of hundreds of kimberlite indicator minerals (KIMs), such as chromium pyrope, magnesian olivine and chromium diopside, recovered from heavy mineral concentrates of samples collected from modern river and stream sediments within the area, showed that the area has a high potential to host local kimberlite sources and can be recommended for further diamond prospecting [1]. The interpretation of aeromagnetic survey results allowed the identification of a local pipe-like anomaly ("KL-01 pipe") within the area. This anomaly was suggested to be a potential kimberlite that should be investigated by drilling. The preliminary results of a deep drilling program that allowed the sampling of the anomalous area to maximum depths of $300 \mathrm{~m}$ showed the existence of reddish-brown sandstones that contained up to $30 \mathrm{vol} . \%$ magmatic material admixture and rare KIMs. Visually, this type of sandstone is similar to the rocks that compose the ADP kimberlite craters. However, the whole-rock composition of the KL-01 rock samples is not comparable with the known ADP magmatic rock composition because the sediment component prevails over the magmatic component.

Identifying the type of magmatic material present in the KL-01 sandstones is required to determine the feasibility of further drilling of the anomaly and the diamond potential of the study area. Therefore, in this paper, I present a detailed geochemical study of the KL-01 sandstones (35 samples) together with data on samples from the crater parts of several ADP magmatic pipes, namely, the V. Grib (30 samples), Pobeda and Yurasskaya kimberlite pipes (two samples), the Suksoma olivine melilitite/picrite pipe (one sample) and Vendian sandstones (two samples). These data are used to create a step-by-step process for identifying the type of magmatic material admixture in the ADP sandstones, which can be useful at the stages of test drilling in pipe-like anomalies. Data on KIM (62 grains) major element compositions and trace element contents in 21 pyropes are also presented in the current study to obtain information about the composition, structure and thermal state of the lithospheric mantle beneath the KL-01 pipe, as well as its suitability for the formation and preservation of diamonds.

\section{Geological Background}

The Devonian-upper Carboniferous ADP (390-340 Ma; [8]) occurs in the southern Kola Craton [1,4] and includes several magmatic fields (Figure 2). The ADP magmatic rocks are present in the form of pipes, dykes, sills and various combinations, and they intrude into Vendian sedimentary rocks (sandstones, siltstones and mudstones) and are covered by middle Carboniferous to Permian terrigenous and carbonate rocks and unconsolidated Cenozoic sediments [9-12]. The summarized data on the ADP magmatic bodies, including location, form, size, structure and composition are presented in Tables S1 and S2 and Figures S1 and S2 in Supplementary Material.

The "K" area $\left(1978 \mathrm{~km}^{2}\right)$ is located in the southern part of the ADP and borders the Kepino and Turiyno fields on the north (Figure 2). To date, no magmatic bodies have been discovered within the area (with the exception of the KL-01 pipe, which is discussed here). However, the geophysical data point to the existence of numerous submeridional linear structures (i.e., fault zones) within all territories of the area (Figure 2). Most of the ADP magmatic pipes, including the diamondiferous kimberlites, are located within these linear structures; therefore, these structures are worthy of diamond exploration because they may contain undiscovered magmatic pipes [1]. 


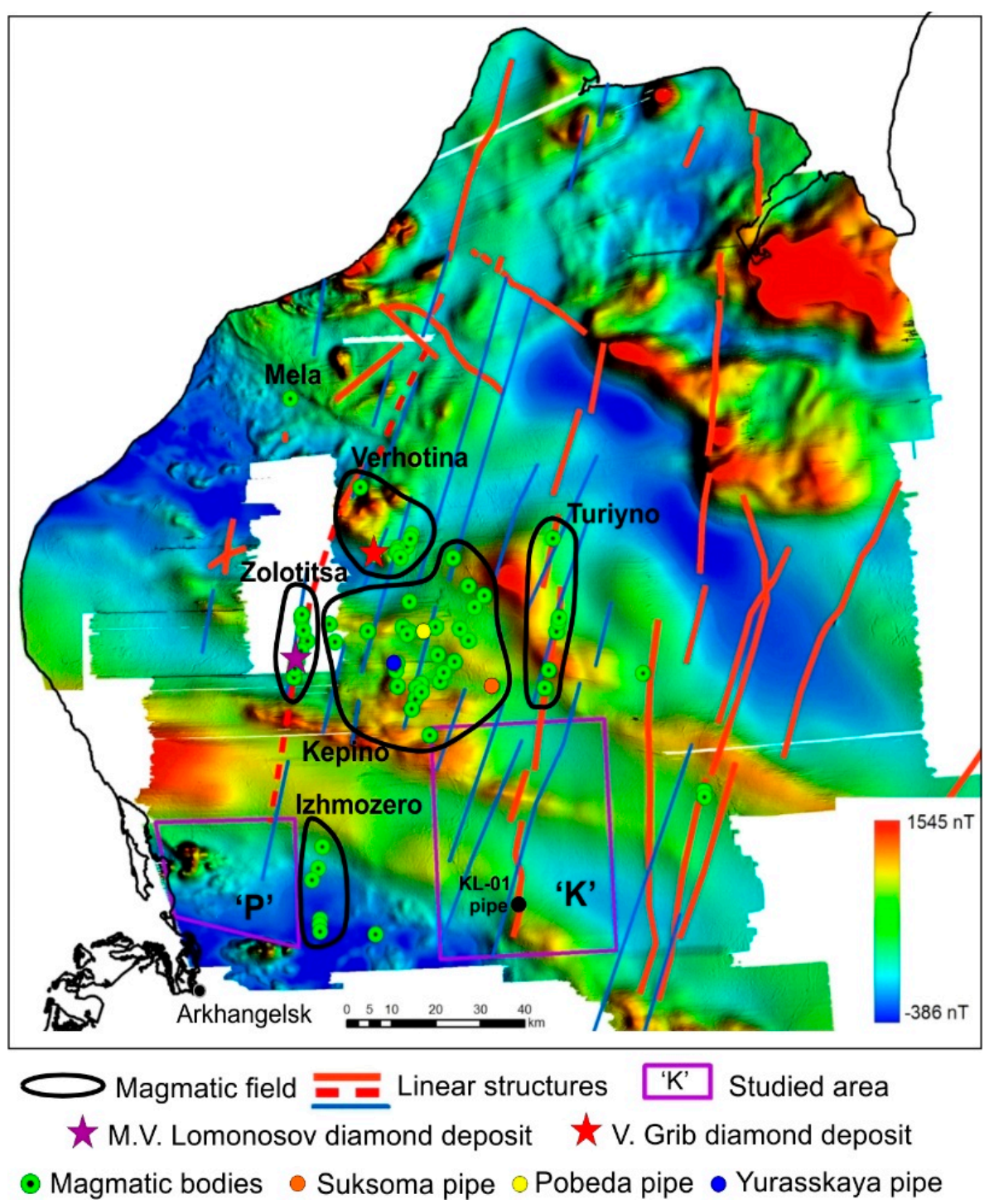

Figure 2. Map of anomalous magnetic field $\Delta \mathrm{T}$ for the Arkhangelsk Diamondiferous Province (ADP) and location of the KL-01 pipe. Adapted from [1].

The KL-01 pipe is located in the southern part of the " $\mathrm{K}$ " area. The pipe was identified as an anomaly of 12-13 nT in the local magnetic field by a ground magnetic survey (Figure 3). The pipe was sampled in three boreholes located in the central (no. 1), northern (no. 2) and southern (no. 3) parts of the anomaly to depths of 150 and $300 \mathrm{~m}$. The pipe intrudes into Vendian sedimentary rocks and is covered by middle Carboniferous, Permian and Cenozoic sedimentary rocks, with a total thickness of $80 \mathrm{~m}$.

\section{Overview of the Composition of the ADP Magmatic Rocks}

Kimberlites are the predominant rock type in the Zolotitsa field and a component of the Kepino, Verhotina and Mela fields. Defining three main groups of ADP kimberlites is generally accepted $[13,14]$. The first group contains the moderate- to-high-titanium $\left(\mathrm{TiO}_{2}\right.$ from $\sim 2$ to $\left.>3 \mathrm{wt} . \%\right)$ kimberlites of the Kepino field. These kimberlites are the most enriched in high field strength elements (HFSEs- $\mathrm{Nb}, \mathrm{Zr}$ and $\mathrm{Hf}$ ) and light rare earth elements (LREEs) and in terms of $\mathrm{Nd}, \mathrm{Pb}$ and $\mathrm{Sr}$ isotope compositions they are close to Group I kimberlites of southern Africa [15]. The main KIMs are magnesium ilmenite, abundant pyrope and chromium diopside and rare chromium spinel [11]. 


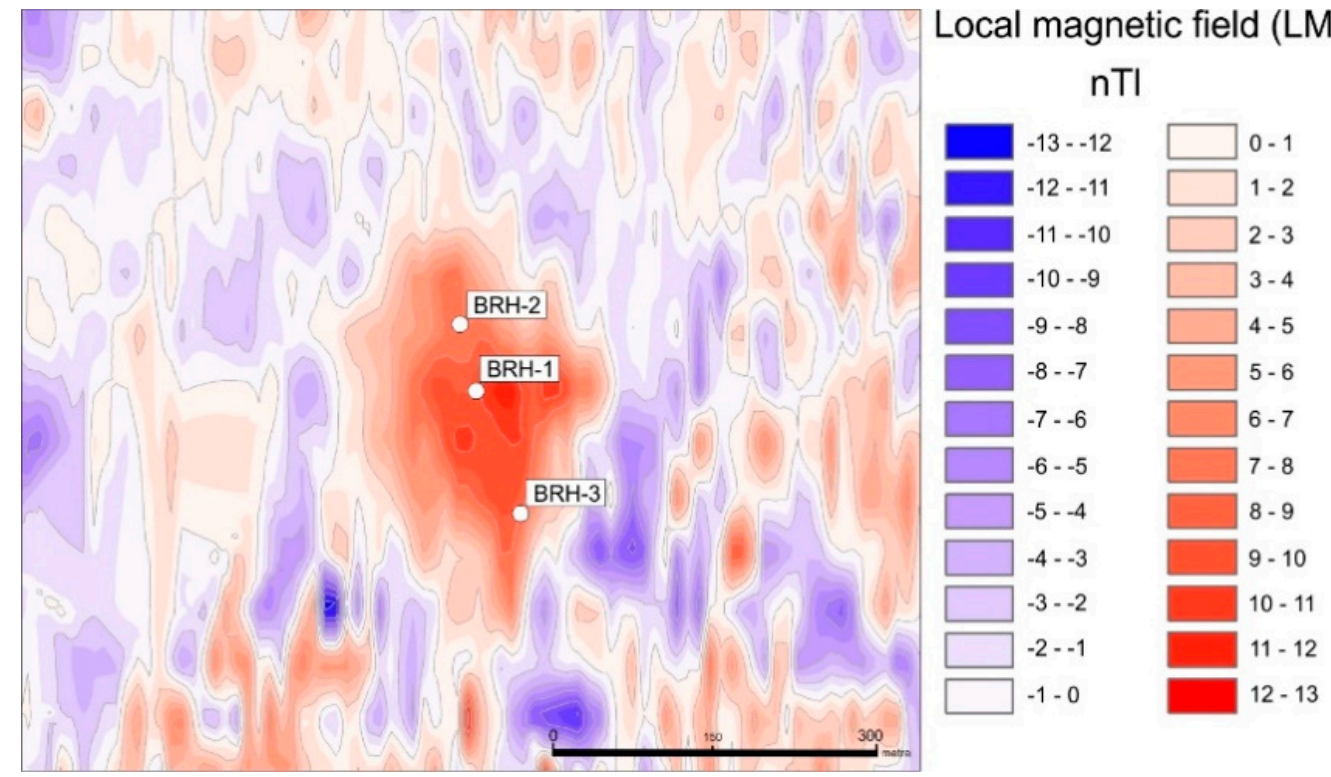

Figure 3. Map of local magnetic field (LMA) generated by a ground magnetic survey for the KL-01 pipe. The location of the KL-01 pipe is shown in Figure 2.

The second group is represented by low-titanium $\left(\mathrm{TiO}_{2}<1 \mathrm{wt} . \%\right)$ kimberlites of the Zolotitsa field. These kimberlites have lower HFSE ( $\mathrm{Nb}, \mathrm{Zr}$, and Hf) and LREE contents and are close to the Group II kimberlites of southern Africa [15]. The Zolotitsa field kimberlites contain chromium spinel as the dominant KIM, with minor pyrope and chromium diopside and rare magnesium ilmenite $[9,11,16]$.

The third group consists of the moderate-titanium $\left(\mathrm{TiO}_{2}=0.8-2 \mathrm{wt} . \%\right)$ kimberlites of the V. Grib pipe. They are transitional between the Zolotitsa and Kepino field kimberlite compositions in terms of HFSE and LREE $[13,14]$. The V. Grib kimberlites have abundant magnesium ilmenite, pyrope and chromium diopside with minor chromium spinel as KIMs.

The Mela "kimberlites" in fact have compositions that are transitional between kimberlite and carbonatite $\left(\mathrm{SiO}_{2}=15-28 \mathrm{wt} . \% ; \mathrm{MgO}=8-24 \mathrm{wt} . \% ; \mathrm{CaO}=12-34 \mathrm{wt} . \%\right)$. They are enriched in LREEs, Sr and Ba compared to other ADP kimberlites. Information on the presence of KIMs is almost absent in the published literature. Some authors indicate the presence of Mn-ilmenite [17] and rare almandine [10].

Six of the Zolotitsa kimberlites (i.e., the Lomonosov mine) and the V. Grib kimberlite pipe are rich in diamonds and are economically exploitable. The other ADP kimberlites are diamond-poor/free and uneconomic.

Olivine melilitites/picrites are components of the Kepino, Izhmozero and Verhotina fields. The nomenclature of these rocks is debatable. The proponents of the term "picrite" [18,19] indicate that no fresh melilite has ever been found in these rocks, whereas the proponents of the term "melilitites" $[9,11]$ report abundant melilite lithoclasts. All authors define two main varieties of these rocks. The first variety combines mica-poor alkaline picrites [19] or olivine melilitites of Group 1 [9] of the Kepino field, and the second variety combines micaceous picrites [19] or olivine melilitites of Group 2 [9] of the Verhotina and Izhmozero fields. The rocks of the first variety contain more $\mathrm{TiO}_{2}(3.1-3.7 \mathrm{wt} . \%), \mathrm{FeO}(12-15 \mathrm{wt} . \%)$ and $\mathrm{Cr}(1600-2120 \mathrm{ppm})$ than those of the second variety $\left(\mathrm{TiO}_{2}=0.4-1.4 \mathrm{wt} . \% ; \mathrm{FeO}=4-10 \mathrm{wt} . \%\right.$; $\mathrm{Cr}=490-930 \mathrm{ppm}$ ). Types of minerals in heavy mineral concentrates differ for different fields and consist of magnesium ilmenite, pyrope, chromium diopside and chromium spinel in various proportions for the Kepino and Verhotina fields and clinopyroxene and spinel for the Izhmozero field (Table S1). Rare diamond crystals have been found in half of the pipes but not on an industrial scale.

Basalts are the single magmatic rock type identified in the Turyino field. They contain more $\mathrm{SiO}_{2}$ (50-53 wt.\%) and $\mathrm{Al}_{2} \mathrm{O}_{3}(10-13$ wt.\%) and less $\mathrm{MgO}(8-10 \mathrm{wt} . \%), \mathrm{Cr}$ 
(80-240 ppm) and Ni (68-160 ppm) than other ADP magmatic rocks $[9,20]$. The heavy mineral concentrate contains olivine, clinopyroxene and rare garnets with almandine and sparse pyrope compositions.

Carbonatites have been identified within the Mela field. These rocks are poor in $\mathrm{SiO}_{2}$ (5-9 wt.\%), $\mathrm{MgO}$ (4-8 wt.\%) and $\mathrm{FeO}(2-6$ wt.\%) and rich in $\mathrm{CaO}$ (39-46 wt.\%) with low alkali contents $[17,19]$. Compared to Mela "kimberlites", they have lower contents of $\mathrm{TiO}_{2}$ (0.5-1 wt.\%) and Ni (38-334 ppm). There are no diamond crystals in the Mela carbonatites.

\section{Samples and Analytical Techniques.}

\subsection{Samples}

In this study, I provide major and trace element data for 35 sandstone samples from the KL-01 pipe, including 10 samples from borehole-1 (BRH-1) at depths of 125-239 m and 25 samples from borehole-2 (BRH-2) at depths of 85-150 m. For comparison, I also provide the results for two samples of Vendian sandstones sampled near the KL-01 pipe, 30 samples from the crater of the V. Grib kimberlite pipe and three samples from the craters of the olivine melilitite/picrite Suksoma pipe and the Pobeda and Yurasskaya kimberlite pipes in the Kepino field. Note that according to the published data $[10,12,21]$, the Pobeda kimberlite pipe has no crater, but crater sediments have been identified within the boundary of the pipe with Vendian sediments (Figure S2 in Supplementary Material). The sample studied here is far from typical kimberlite or kimberlite xeno-tuff breccia in terms of its mineralogy and major and trace element compositions. Therefore, I describe this sample as a relic of an eroded crater.

Samples of the KL-01 pipe and Vendian sandstones were recovered from the core during 2017-2018 field work on the borehole drilling program organized by the Proex Service. The samples of the V. Grib kimberlite pipe crater were recovered from the open pit in 2015 by the Arkhangelskgeoldobycha (currently AGD Diamonds) geologist. Samples of the crater parts of the Kepino magmatic pipes were taken in 2015 from the Arkhangelskgeoldobycha core collection, obtained by borehole drilling programs in the 1980s-2000s.

\subsection{Analytical Techniques}

All analytical work was performed in the Analytical Center for Multi-Element and Isotope Research at the Sobolev Institute of Geology and Mineralogy, Siberian Branch of the Russian Academy of Science (IGM SB RAS), Novosibirsk.

Billets of $\sim 25 \mathrm{~mm} \times 45 \mathrm{~mm} \times 10 \mathrm{~mm}$ were cut with a diamond blade, planed on one side and mounted with epoxy on standard $\sim 27 \mathrm{~mm} \times 47 \mathrm{~mm}$ petrographic carrier glass. To assess mineral content, microtexture, structure and fabric, covered thin sections were examined by backscattered electron imaging using a Tescan MIRA 3 LMU scanning electron microscope (SEM) (Tescan) coupled with an INCA energy dispersive spectroscopy (EDS) microanalysis system 450 with a liquid nitrogen-free large area EDS X-Max-80 silicon drift detector (Oxford Instruments). To evaluate the bulk rock major and trace element contents, the samples were powdered using tungsten-carbide. Silicate analysis for 15 major oxides was carried out on an ARL-9900-XP X-ray fluorescence spectrometer. The relative standard deviations were $<1$ wt. $\%$ for $\mathrm{SiO}_{2}, \mathrm{FeO}$ and $\mathrm{TiO}_{2} ; 1.1-1.7$ for $\mathrm{Al}_{2} \mathrm{O}_{3}, \mathrm{MgO}$ and $\mathrm{TiO}_{2} ; 2.5$ wt.\% for $\mathrm{Cr}_{2} \mathrm{O}_{3}$; and 3.4-3.5 wt.\% for $\mathrm{MnO}, \mathrm{Na}_{2} \mathrm{O}$ and $\mathrm{K}_{2} \mathrm{O}$. The contents of 32 trace elements were analyzed on a high-resolution ELEMENT (Finnigan Mat) inductively coupled plasma (ICP) mass spectrometer with a U-5000AT pulverizer ultrasound, following the method elaborated by the IGM SB RAS [22]. The relative standard deviation of the analysis amounted to $2-5 \%$ on average [22]. To identify the rock-forming minerals and their proportions, X-ray diffractometry on an automatic piston DRON-4 diffractometer equipped with a graphite monochromator (CuK radiation, voltage of $40 \mathrm{kV}$, current of $24 \mathrm{~mA}$ ) was used. The detection limit of the minerals was 1 vol.\%. To diagnose the group of clay minerals, samples were saturated with ethylene glycol. To define smectites as dioctahedral (montmorillonite group) or trioctahedral (saponite group), the values of $\mathrm{d}_{060}$ were used $\left(\mathrm{d}_{060}=1.453-1.503 \AA\right.$ for dioctahedral and $\mathrm{d}_{060}=1.503-1.543 \AA$ for trioctahedral varieties $)$. 
Three hundred $\mathrm{kg}$ of KL-01 pipe rocks, including $200 \mathrm{~kg}$ from borehole 1 and $100 \mathrm{~kg}$ from borehole 2, were crushed and then processed via magnetic and heavy liquid separation. The mineral concentrates were handpicked for KIMs under a binocular microscope. Two fresh olivine grains were picked directly from the greenish segregations in sample KL01-2144.3. In total, 328 mineral grains were picked and subjected to morphological study and microprobe analysis. The KIM morphology was studied using a MIRA 3 LMU (Tescan, Ltd.) SEM, equipped with an INCA Energy 450 X-Max-80 EDS (Oxford Instruments, Ltd.). Then, the minerals were mounted in epoxy, polished and coated with carbon. The major element compositions of the minerals were measured using a JEOL JXA-8100 electron probe microanalyzer (EPMA). The analytical conditions were a $20-\mathrm{kV}$ accelerating voltage and a 50-nA beam current, with a beam size of $1 \mu \mathrm{m}[23,24]$. In-house natural mineral IGM SB RAS standards were used for calibration. Relative standard deviations were within $1.5 \%$. Data were acquired for $10 \mathrm{~s}$ on-peak as well as $10 \mathrm{~s}$ on either side of the background; ZAF correction was applied. Detection limits were $<0.05 \mathrm{wt} . \%$ for all elements analyzed, including $0.01 \mathrm{wt} . \%$ for $\mathrm{Cr}$ and $\mathrm{Mn}, 0.02 \mathrm{wt} . \%$ for Ti and $\mathrm{Na}$, and $0.05 \mathrm{wt} . \%$ for K. Based on the results of the microprobe analysis, 62 grains were identified as potential KIMs, including 32 garnets, 16 chromium spinels, eight magnesian ilmenites, two olivines and four chromium diopsides, and 266 garnet grains were identified from non-mantle lithologies. In situ trace element analyses in pyropes were carried out using a Thermo Scientific XSeries 2 ICP mass spectrometer using a Nd:YAG LaserProbe system (Thermo Fisher Scientific Inc., Waltham, MA, USA) at the Analytical Center of Novosibirsk State University. Reference samples SRM NIST 612 and NIST 614 were used for calibration of instrument parameters. Two analyses of the NIST 612 standard were completed before and after analysis of ten samples to correct for machine drift. The laser was operated at $20 \mathrm{~Hz}$ with a pulse energy of $12 \mathrm{~mJ} \mathrm{~cm}{ }^{2}$ and a beam size of $50 \mu \mathrm{m}$. Helium was used as the carrier gas. The acquisition times were $90 \mathrm{~s}$ for the background and $60 \mathrm{~s}$ for the signal. The detection limits were within 0.1-0.2 ppm for elements with lighter mass (Sc-Sr), and $0.01 \mathrm{ppm}$ for elements with masses heavier than that of Sr. The low concentrations ( $\sim 0.8 \mathrm{ppm})$ of SRM NIST 614 were analyzed three times as unknowns and gave $<10 \%$ deviation from recommended values [25] for most of the elements except $\mathrm{Sc}, \mathrm{Ti}, \mathrm{Ni}$ and $\mathrm{Rb}$, which were within 25\%. The EPMA-determined Ca concentrations were used as internal standards.

\section{Petrography}

Photographs of the representative samples studied here are presented in Figure 4.

The Vendian sandstones are reddish-brown, poorly cemented rocks composed mostly of quartz with accessory K-feldspar, zircon, hematite and anatase and aggregates of kaolinite (Figure $4 \mathrm{~A}$ ).

The KL-01 pipe is composed of reddish-brown sandstones that contain oval greenish segregations up to $2 \mathrm{~cm}$ in size, rare massive veins and oval-to-elongated formations up to $7 \mathrm{~cm}$ in size (Figure 4B-J). These segregations are xenogeneic to the sandstones and are similar to those found in sedimentary rocks of the crater parts of the ADP magmatic pipes, so I describe them as magmatic material (MM) admixtures. The MM is clearly visible in the sandstones sampled deeper than $140 \mathrm{~m}$ in borehole 1 and $80 \mathrm{~m}$ in borehole 2 . The volume percentage of $\mathrm{MM}$ increases in the following sequence: $<1 \mathrm{vol} . \%$ at depths of $140-170 \mathrm{~m} ; 1-10$ vol.\% at $170-250 \mathrm{~m}$ for borehole 1 and $10-20$ vol. $\%$ at $80-140 \mathrm{~m}$ and 20-30 vol.\% at 140-150 $\mathrm{m}$ for borehole 2 (Figure 5A). The main rock-forming minerals of the sandstones are quartz and K-feldspar with frequent accessory minerals such as zircon, rutile, brookite/anatase, ilmenite, biotite, barite, hematite, magnetite, Ti-magnetite and rare amphibole, apatite, monazite and muscovite and sporadic perovskite and sulfides (pyrite, Co-Fe sulfide; Figure 6A). The groundmass in sandstones is composed of mixtures of the same minerals with smaller sizes and contains abundant segregations of secondary phases such as calcite, chlorite, dolomite, kaolinite and rare illite. The MM is present mostly as dioctahedral smectite (montmorillonite), rarely as trioctahedral smectite (saponite) and 
chlorite or a mixture of them, and can contain segregations of calcite, barite, Fe-oxides, kaolinite, ilmenite and rare K-feldspar (Figure 6B,C).
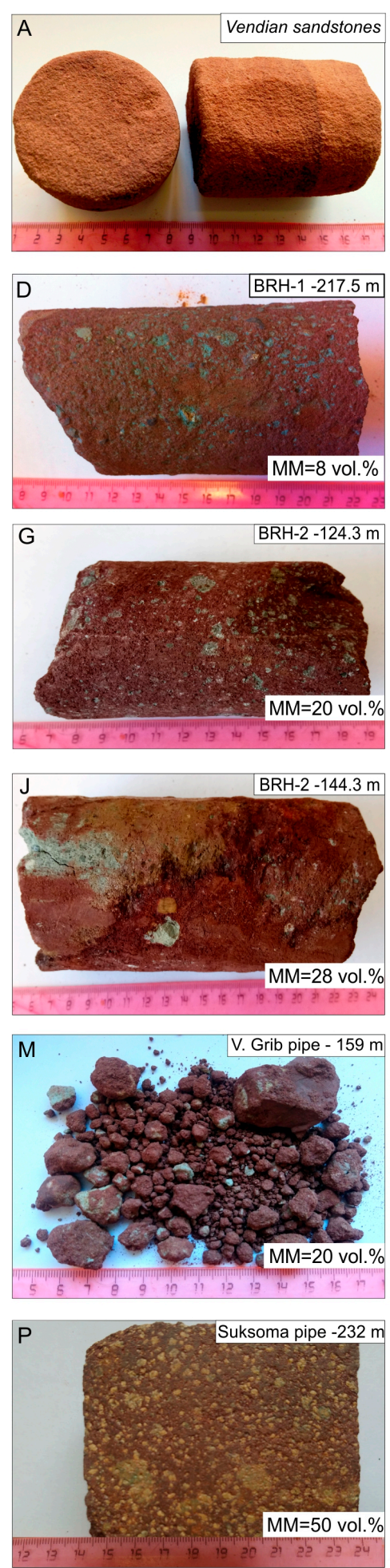
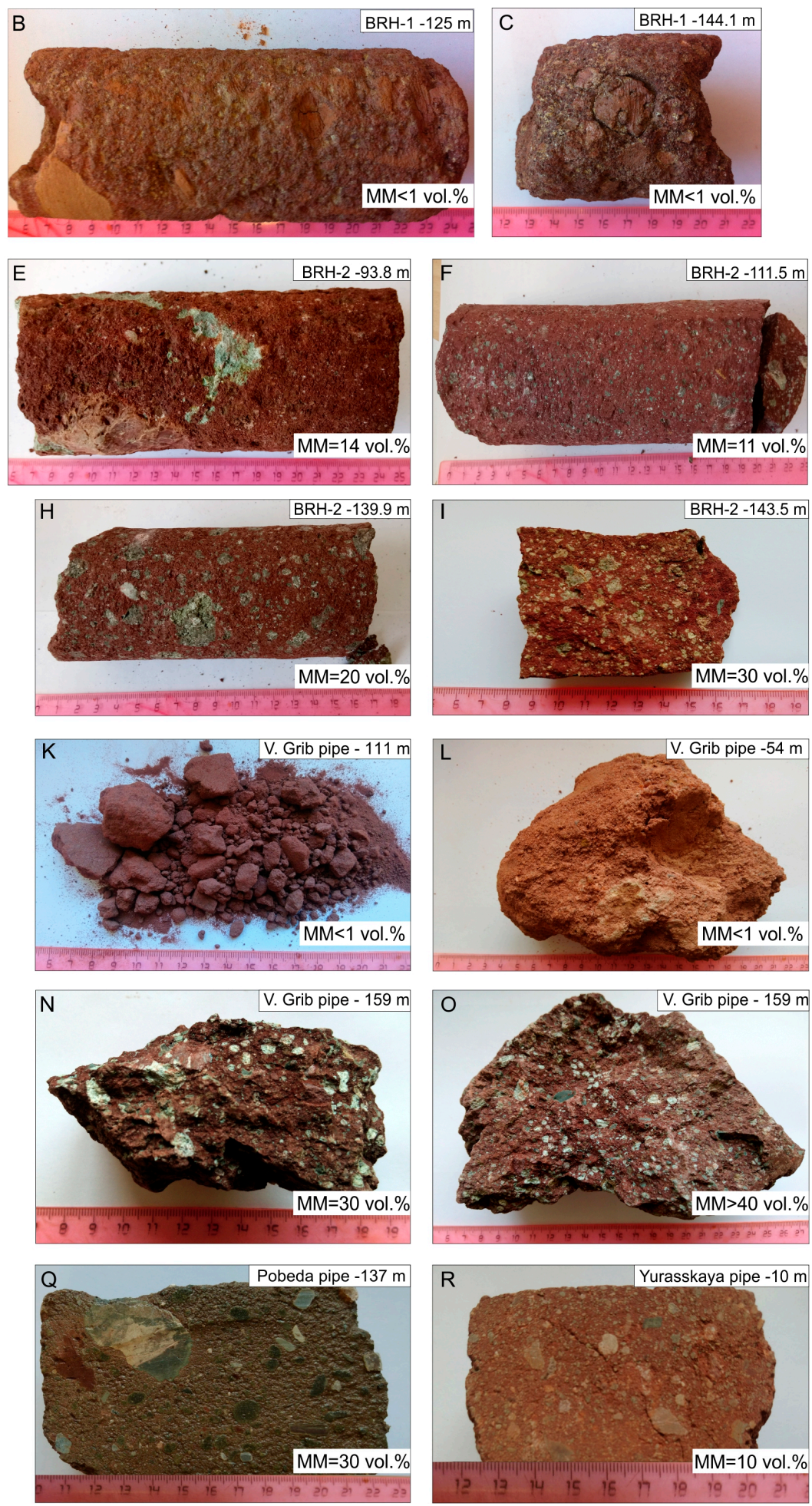

Figure 4. Photographs of the representative studied samples. (A) Vendian sandstone; (B-J) KL-01 pipe; (B-D) from borehole-1 (BRH-1), (E-J) from borehole-2 (BRH-2); (K-Q) sandstones from the crater part of the V. Grib kimberlite pipe; (P) sandstone from the crater of the Suksoma olivine melilitite/picrite pipe; $(\mathbf{Q}-\mathbf{R})$ sandstones from the crater parts of Pobeda $(\mathbf{Q})$ and Yurasskaya (R) kimberlite pipes. Depth of sampling is marked from the surface. Schematic sections of the magmatic pipes are shown on Figure S2. 

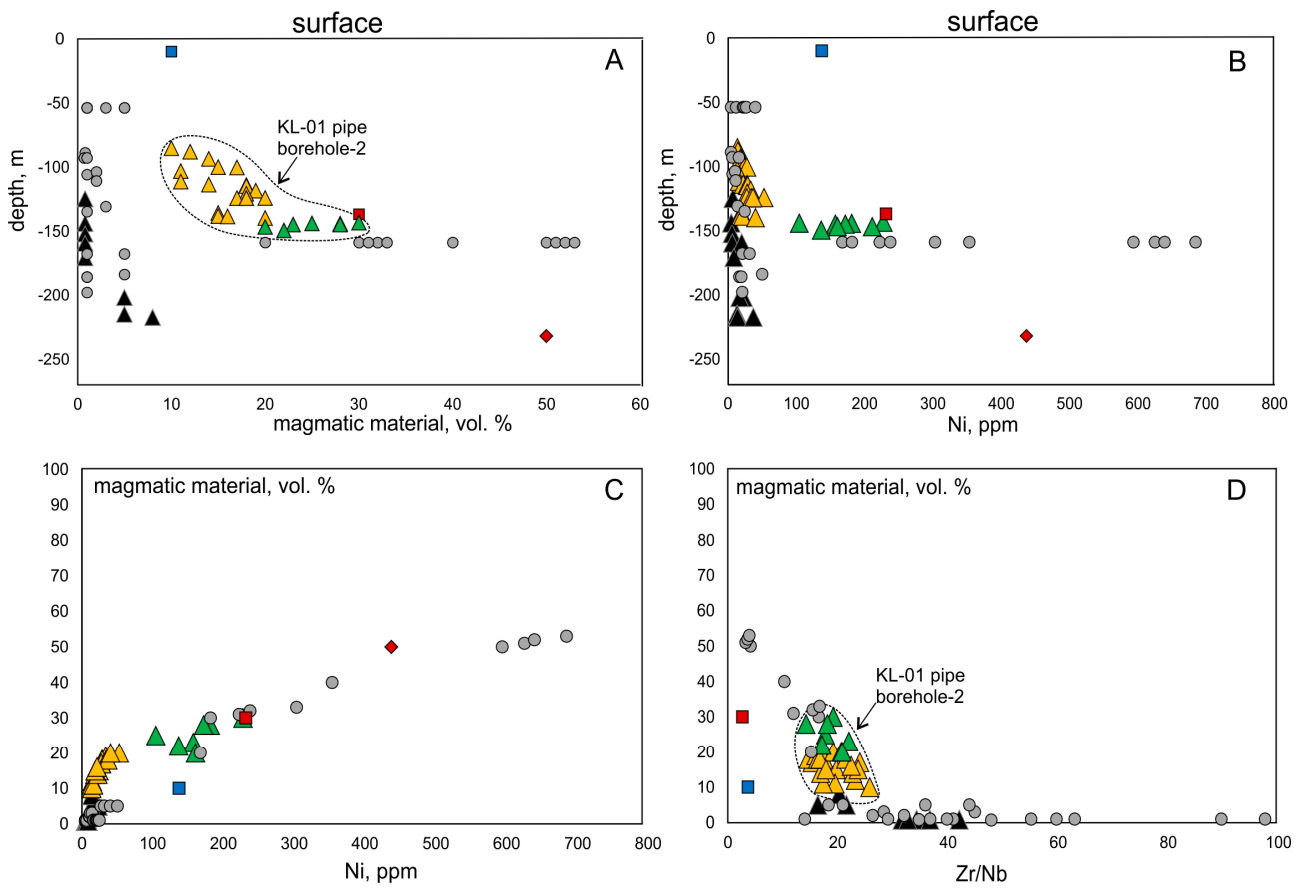

$\Delta \mathrm{KL}-01$ borehole $1 \Delta \mathrm{KL}-01$ borehole 2 80-140 m $\Delta \mathrm{KL}-01$ borehole 2 140-150 m $\square$ Pobeda kimberlite pipe

$\diamond$ Suksoma picrite/olivine melilitite pipe $\bigcirc$ V. Grib kimberlite pipe $\quad$ Yurasskaya kimberlite pipe

Figure 5. The correlations of depth of samples with volume $\%$ of magmatic material (A) and Ni content (B), and volume \% of magmatic material with $\mathrm{Ni}$ content $(\mathbf{C})$ and $\mathrm{Zr} / \mathrm{Nb}$ ratio (D) in the ADP crater sandstones.
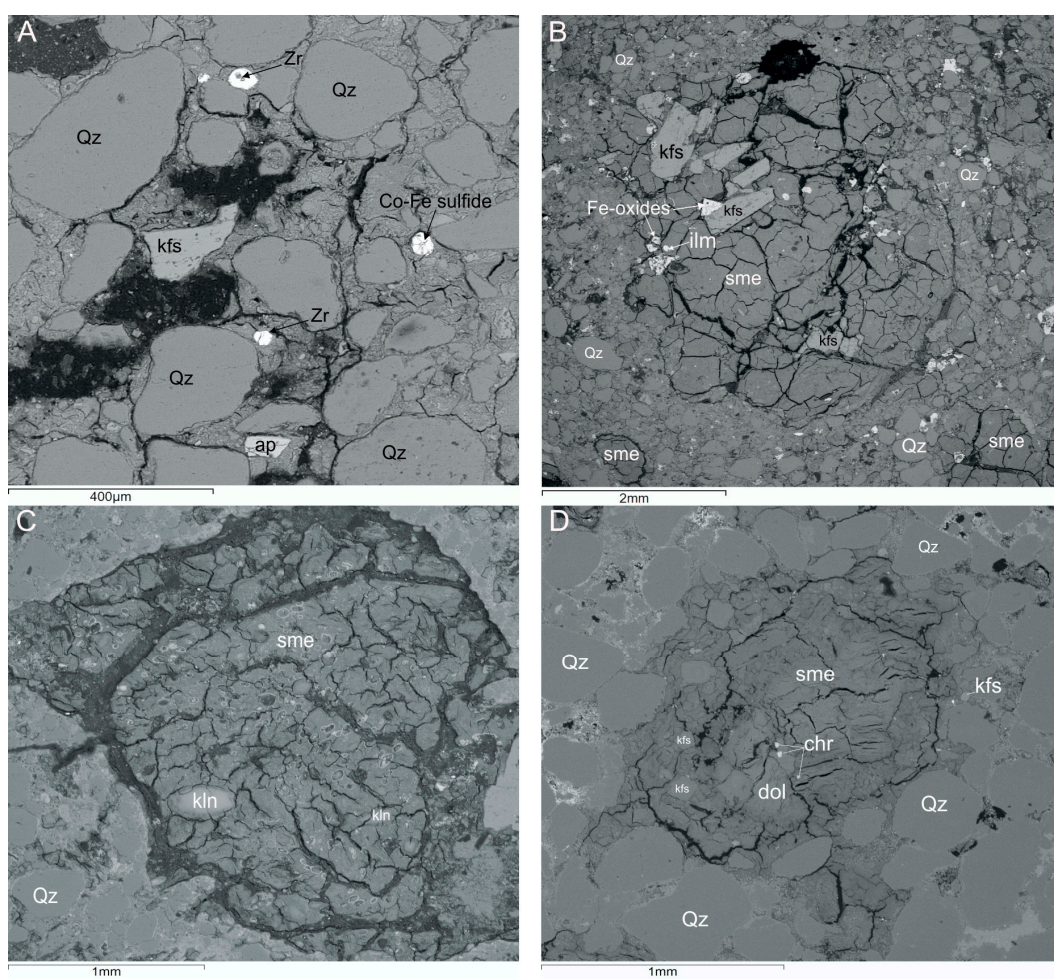

Figure 6. Back-scattered electron images of thin section of sandstones from the KL-01 pipe (A-C) and Suksoma olivine melilitite/picrite pipe (D). Qz = quarts, $\mathrm{kfs}=\mathrm{K}$-feldspar, Sme = smectite, $\mathrm{Zr}=$ zircon, $\mathrm{Ap}=$ apatite, $\mathrm{ilm}=$ ilmenite, $\mathrm{kln}=$ kaolinite, $\mathrm{dol}=$ dolomite, $\mathrm{chr}=\mathrm{Cr}$-spinel. Abbreviations of minerals according to [26]. 
The crater sediments of the V. Grib kimberlite pipe are present as rock series varying from reddish-brown, almost loose sandstones with no visible MM (Figure 4K) to poorly cemented sandstones with MM present as chaotic light green segregations up to $2 \mathrm{~cm}$ in size ( $\mathrm{MM}<20$ vol.\%; Figure $4 \mathrm{~L}, \mathrm{M})$ to well-cemented dense sandstones containing oval and oval-elongated greenish segregations varying from 20 vol. $\%$ (Figure $4 \mathrm{~N}$ ) to $>40$ vol. $\%$ (Figure 4O). The volume percentage of MM does not correlate with the depth of the sample because the samples were recovered not from a specific borehole but from the open pit, so the whole series of crater sediment can be present within a similar depth (Figure 4M-O and Figure 5A). The sandstones are composed of dominant quartz and subordinate K-feldspar, with frequent accessory minerals such as mica, hematite, rutile and rare amphibole and plagioclase. The secondary phases are kaolinite, chlorite, dolomite and rare calcite and illite. The MM is represented by montmorillonite, saponite or a mixture of them in samples with $20<\mathrm{MM}<40$ vol.\% and by saponite and rare vermiculite-saponite in the samples with $\mathrm{MM}>40$ vol.\%.

The crater sediments of the melilitite/picrite Suksoma pipe (Kepino field) are composed of well-cemented reddish-brown sandstone that contains 50 vol. \% MM in the form of oval greenish segregations up to $1.5 \mathrm{~cm}$ in size (Figure $4 \mathrm{P}$ ). The sandstone is composed of dominant quartz and subordinate K-feldspar with frequent accessory minerals such as mica, hematite, zircon and rare amphibole. The secondary phases are predominant calcite and rare chlorite, dolomite and barite. The MM is present as saponite and can contain segregations of calcite, dolomite and chlorite. Small (up to $30 \mu \mathrm{m}$ ) grains of chromium spinel are identified within most MM segregations (Figure 6D).

The crater sediments of the Pobeda and Yurasskaya kimberlite pipes (Kepino field) are well-cemented reddish-brown and brown sandstones with $\mathrm{MM}<30$ vol.\% (Figure 4Q,R). The sandstones are composed of dominant $\mathrm{Qz}$ and subordinate K-feldspar with frequent accessory minerals such as rutile, zircon and hematite and rare mica, magnetite and apatite. The secondary phases are dominant dolomite and rare calcite, chlorite and kaolinite. The $\mathrm{MM}$ is represented by saponite with rare segregations of dolomite and chlorite in the sample from the Pobeda pipe and dolomite in the sample from the Yurasskaya pipe.

\section{Results}

\subsection{Major and Trace Element Whole-Rock Geochemistry}

The major and trace element compositions of the samples are presented in Table S3.

The Vendian sandstones are $\mathrm{SiO}_{2}$-rich (93-96 wt.\%) and have low contents of other oxides. The contents of the majority of measured trace elements are negligible (0.1-10 ppm) with the exception of Ba (14-24 ppm), LREEs ( $\mathrm{La}=9-17$ ppm; Ce $=19-35$ ppm), Sr (47-83 ppm), $\mathrm{Zr}$ (83-427 ppm) and Y (10-35 ppm) and reflect the mineral assemblage in rocks.

The sandstones of the KL-01 pipe have variable major element compositions; $\mathrm{SiO}_{2}$ and other main oxides correlate negatively, which indicates the ratio of sandstone to MM constituents (Figure 7A). The $\mathrm{SiO}_{2}$ contents are higher in the samples from BRH-1 $\left(\mathrm{SiO}_{2}=70-88\right.$ wt.\%) than in the samples from BRH-2 $\left(\mathrm{SiO}_{2}=47-72\right.$ wt.\%). Two BRH-1 samples (KL01-1-17K and KL01-1-23K) composed predominantly of MM were used for whole-rock (WR) analyses and have lower $\mathrm{SiO}_{2}$ contents (51 and 47 wt.\%, respectively) and higher concentrations of other oxides and are similar to the samples from BRH2. The $\mathrm{MgO}$ contents vary within the range of 0.1-2.1 wt.\% for BRH-1, 3.8-5.1 wt.\% for samples KL01-1-17K and KL01-1-23K and 1.3-5.3 wt.\% for BRH-2. Compared to the Vendian sandstones, the KL-01 samples have higher contents of all measured trace elements and similar concentrations of Zr (180-366 ppm). The KL-01 samples have nearly constant concentration of $\mathrm{Cr}(11-60 \mathrm{ppm})$ and variable Ni content (Figure 5B-C and Figure 7B). The Ni concentrations vary from 5 to 53 ppm in the samples with <20 vol.\% MM. The BRH-2 samples with 20-30 vol.\% MM are enriched in Ni (104-227 ppm; Figure 5B-C and Figure $7 \mathrm{~B}$ ). The $\mathrm{Zr} / \mathrm{Nb}$ ratio correlates negatively with the volume of MM (Figure 5D). 

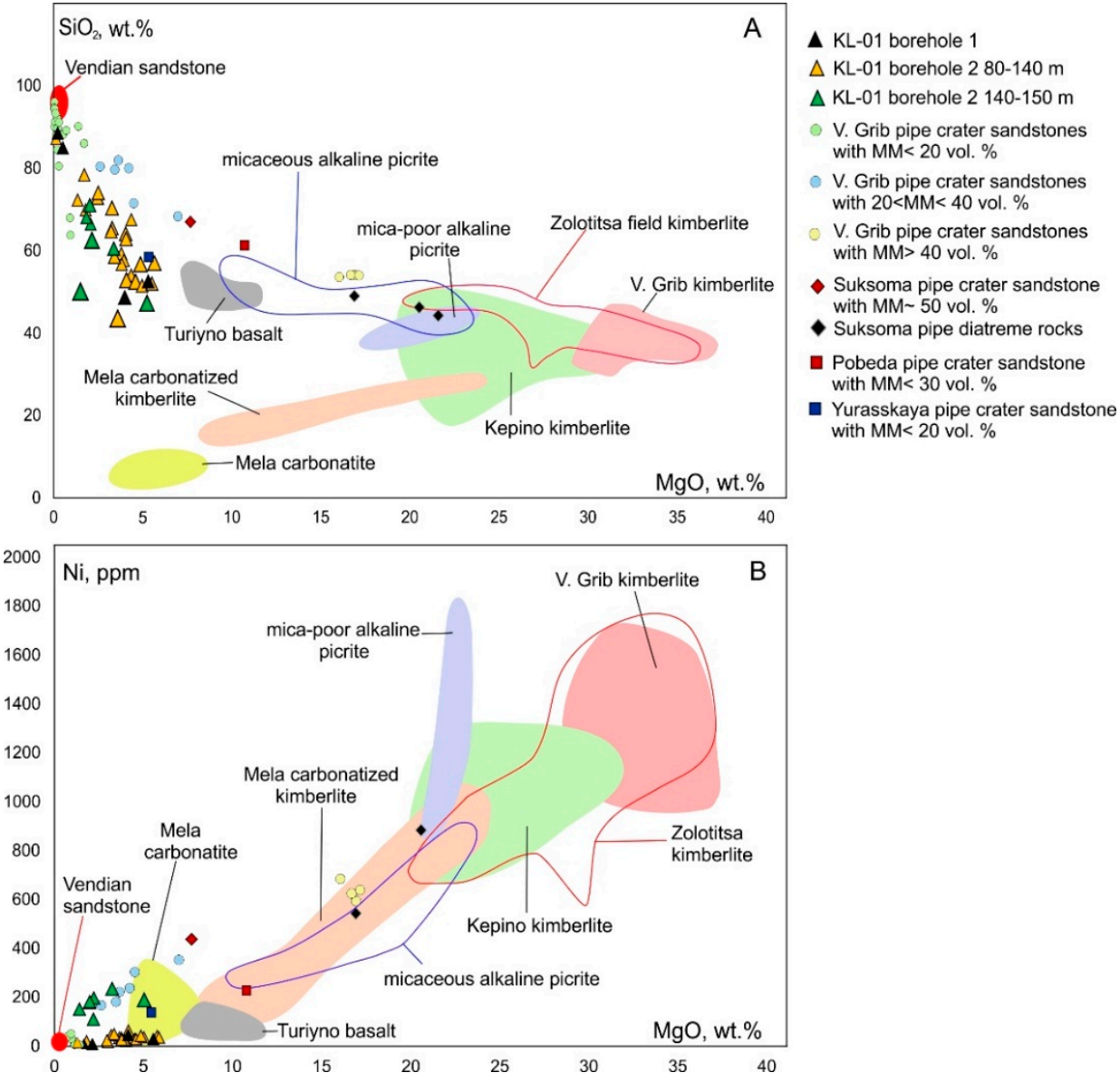

Figure 7. $\mathrm{SiO}_{2}-\mathrm{MgO}$ (A) and $\mathrm{Ni} / \mathrm{MgO}$ (B) relations diagrams for the KL-01 pipe sandstones, crater sediments of the V. Grib, Pobeda and Yurasskaya kimberlite pipes and Suksoma olivine melilitite/picrite pipe. The error bars are smaller than symbol size. Data for the ADP magmatic rocks from $[9,10,13,14,17,19,20,27]$.

The crater sediments of the V. Grib kimberlite pipe have $\mathrm{SiO}_{2}$ contents varying from 96 to $54 \mathrm{wt}$ \% and correlate negatively with MM modes and major oxides (Figure 7A). The contents of $\mathrm{MgO}$ vary from $0.06 \mathrm{wt} . \%$ to $17 \mathrm{wt} . \%$ and correlate positively with $\mathrm{Ni}$ and $\mathrm{MM}$ modes (Figures 5C and 7B; Table S3). The maximum concentrations of Ni (up to $685 \mathrm{ppm}$ ) and $\mathrm{Cr}$ (up to $727 \mathrm{ppm}$ ) are higher than those of the KL-01 samples.

The crater sample of the Suksoma olivine melilitite/picrite pipe is $\mathrm{SiO}_{2}$-rich (67 wt.\%) and $\mathrm{MgO}$-poor (7.7 wt.\%) with low contents of other oxides. When compared with V. Grib pipe crater sedimentary rocks having $\mathrm{MM}>40$ vol.\%, the Suksoma sample has lower $\mathrm{MgO}$, Cr (168 ppm), Ni (437 ppm) and LREE contents.

The crater sediments of Pobeda and Yurasskaya kimberlite pipes (Kepino field) have $\mathrm{SiO}_{2}$ contents varying within the range of 58-61 wt.\% and $\mathrm{MgO}$ from 5.3 to $10.7 \mathrm{wt} \%$. The $\mathrm{Ni}$ (137-231 ppm) content is within the range of the BRH-2 KL-01 samples, whereas the $\mathrm{Cr}$ contents are significantly higher $(\mathrm{Cr}=421-575 \mathrm{ppm})$ and close to those from the V. Grib pipe. On discrimination diagrams, the Kepino samples overlap or are close to the V. Grib pipe samples (Figures 5 and 7A).

\subsection{Morphology of Kimberlite Indicator Minerals from the KL01 Pipe}

Garnets are represented by grains with elongated angular shapes (Figure 8A,C-E) or with relics of a rhombic dodecahedral habit (Figure $8 \mathrm{~B}$ ); they are various shades of red (light red, deep red and purple-red) and range in size from 1 to $2 \mathrm{~mm}$. The surfaces of the grains can be smooth (in some cases, apparently as a result of grain cleavage) with relics of a pyramidal shingle-like relief (Figure 8A) or have signs of melting, recognized 
by microrelief forming minute waves and humps (Figure 8B). Three grains have rare signs of chemically corroded morphology with the formation of negative forms such as etching channels (Figure 8C) and positive forms such as "drop-like" relief (Figure 8D,E). Magnesium ilmenite grains are oval or oval-elongated and 1-2 $\mathrm{mm}$ in size with rough relief and have no clear pyramidal shingle-like forms (Figure 8F). Chromium spinel is represented by grains up to $1 \mathrm{~mm}$ in size, mostly with relic octahedral habit, and having rough relief around the smooth surfaces of octahedron faces (Figure 8G). A minor number of grains do not preserve any clear crystallographic forms and have overall rough relief. Chromium diopside and olivine grains are up to $1 \mathrm{~mm}$ in size and have clear pyramidal shingle-like microrelief formed by minute "drops" and "tubercles" (Figure 8H,I).
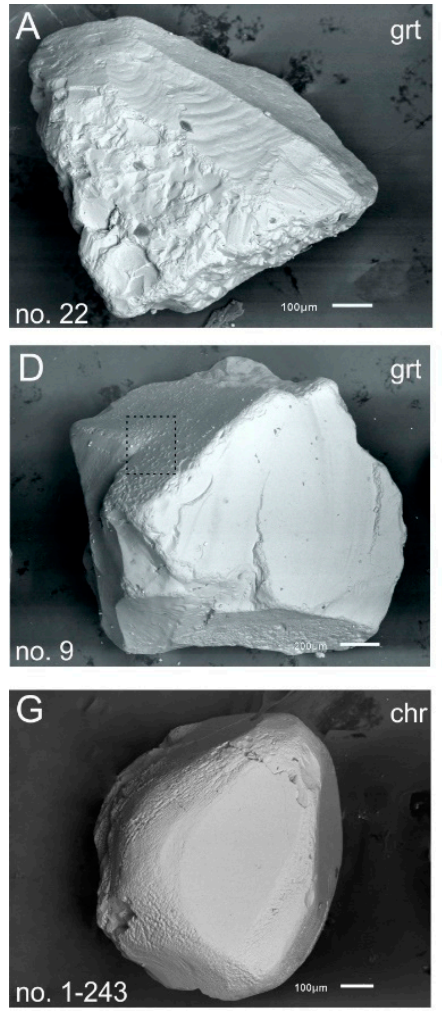
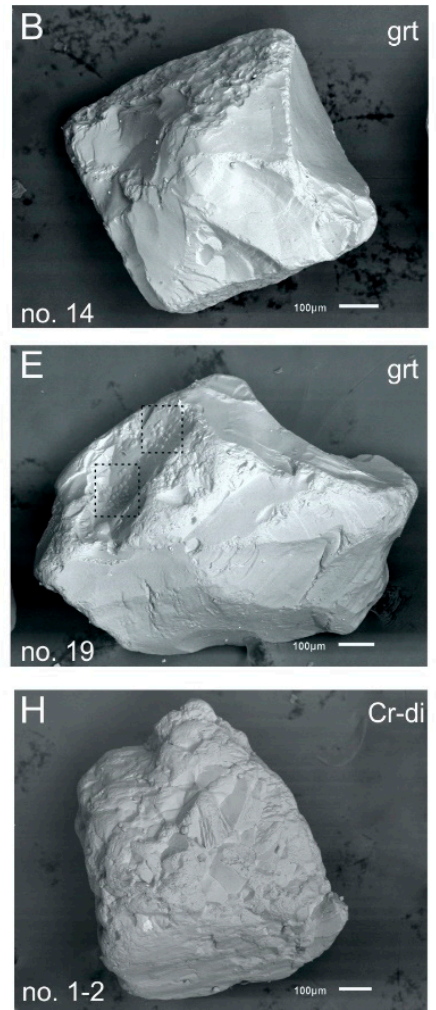
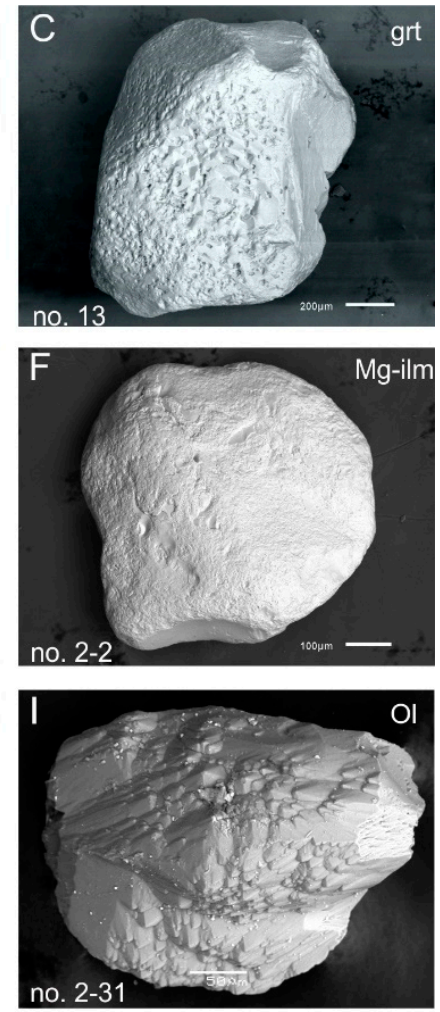

Figure 8. Back-scattered electron images of kimberlite indicator minerals (KIMs) from the KL-01 pipe. (A-E): garnet (grt), (F): Mg-ilmenite, (G): chromite (chr), (H): Cr-diopside (Cr-di), (I): olivine (ol). A, $\mathrm{E}$ and $\mathrm{F}$ - with relics of a pyramidal shingle-like relief; $\mathrm{B}$ - with signs of melting; $\mathrm{C}-\mathrm{E}$ with signs of chemical corrosion, C-with etching channels, D and E-with "drop-like" relief; F-with rough relief.

\subsection{Geochemistry of Kimberlite Indicator Minerals from the KL01 Pipe}

The major and trace element compositions of the KIMs are presented in Table S4 in Supplementary Material.

\subsubsection{Garnet}

Among 32 garnet grains identified as potential KIMs, twenty-five garnets ( $78 \%$ of the total garnet population) are high-magnesium $(\mathrm{Mg} \#=0.80-0.84)$ pyropes $\left(\mathrm{Pyr}_{67-75} \mathrm{Alm}_{13-18}\right.$ Gross $\left._{11-18}\right)$. Seven garnets $(22 \%)$ are low in magnesium $(\mathrm{Mg} \#=0.44-0.70)$, including six garnets with transitional pyrope-almandine compositions ( $\left.\mathrm{Pyr}_{32-59} \mathrm{Alm}_{25-41} \mathrm{Gross}_{12-27}\right)$ and one grain with a high grossular component $\left(\mathrm{Pyr}_{40} \mathrm{Alm}_{18} \mathrm{Gross}_{42}\right)$, which could be of eclogitic paragenesis [28]. The compositions of these garnets match those from the V. Grib pipe coarse-grained eclogites ([29]; Figure S3 in Supplementary Material).

Following the classification scheme outlined by [30], all the pyropes match the field of lherzolite garnets (Figure 9A). Based on their C1 [31] chondrite-normalized rare earth 
element (REEn) patterns as well as their $\mathrm{Cr}_{2} \mathrm{O}_{3}, \mathrm{Zr}$ and $\mathrm{Y}$ contents, pyropes can be classified into five principal groups.

The first group (1 grain; $5 \%$ of the total lherzolitic pyrope population, here and afterwards) is represented by a pyrope that has fractionated patterns from middle (M) REEs to heavy $(\mathrm{H})$ REEs $\left(\mathrm{Yb}_{\mathrm{n}}=8 \times\right.$ chondritic; $\mathrm{Yb}_{\mathrm{n}} / \mathrm{Sm}_{\mathrm{n}}=12$; Figure 10A). The MREE contents are near the $\mathrm{C} 1$ chondrite values $\left(\mathrm{Sm}_{\mathrm{n}}=0.7 \times\right.$ chondritic). This pyrope has low $\mathrm{Zr}(2 \mathrm{ppm})$ and $\mathrm{Y}(6 \mathrm{ppm})$ contents (Figure $9 \mathrm{~B})$ and matches the field of "depleted" pyropes from the V. Grib pipe peridotites and xenocrysts [32,33] and Mir pipe xenocrysts [34]. The pyrope has a low $\mathrm{Cr}_{2} \mathrm{O}_{3}$ content (3.3 wt.\%) and negligible $\mathrm{TiO}_{2}(0.05 \mathrm{wt} . \%)$. The concentration of $\mathrm{Ni}$ is $75 \mathrm{ppm}$, which corresponds to an estimated [35] temperature (T) of $1176{ }^{\circ} \mathrm{C}$.

The second group (11 grains; $52 \%$ ) consists of pyropes that have fractionated patterns from MREEs to HREEs $\left(\mathrm{Yb}_{\mathrm{n}}=16-38 \times\right.$ chondritic; $\left.\mathrm{Yb}_{\mathrm{n}} / \mathrm{Sm}_{\mathrm{n}}=3-9\right)$ but elevated MREE contents $\left(\mathrm{Sm}_{\mathrm{n}}=2-5 \times\right.$ chondritic) compared to group 1 (Figure 10B). Pyropes have higher $\mathrm{Y}(13-50 \mathrm{ppm})$ and $\mathrm{Zr}(9-45 \mathrm{ppm})$ contents than group 1 grains and $\mathrm{Y} / \mathrm{Zr}$ ratios of $0.7-3.4$ (Figure 9B). These pyropes are low in chromium $\left(\mathrm{Cr}_{2} \mathrm{O}_{3}=1.7-4.1 \mathrm{wt} . \%\right)$ with minor $\mathrm{TiO}_{2}$ $(0.04-0.2 \mathrm{wt} . \%)$. The Ni concentrations vary within the range of $8-19 \mathrm{ppm}$, corresponding to a small range of $\mathrm{T}=632-779{ }^{\circ} \mathrm{C}$.

The pyropes of the third group ( 6 grains; $29 \%$ ) have flat patterns from MREEs to HREEs $\left(\mathrm{Yb}_{\mathrm{n}}=7-15 \times\right.$ chondritic; $\mathrm{Yb}_{\mathrm{n}} / \mathrm{Sm}_{\mathrm{n}}=1-3$; Figure 10C). Compared to group 2 garnets, these pyropes have lower $\mathrm{Y}$ (9-19 ppm) and similar $\mathrm{Zr}(17-34 \mathrm{ppm})$ contents and lower $\mathrm{Y} / \mathrm{Zr}$ ratios (0.4-0.7). The pyropes have low to moderate $\mathrm{Cr}_{2} \mathrm{O}_{3}$ contents (1.5-5.8 wt.\%) and nearly constant amounts of $\mathrm{TiO}_{2}(0.14-0.3 \mathrm{wt} . \%)$. The $\mathrm{Ni}$ contents vary from $12 \mathrm{ppm}$ to $70 \mathrm{ppm}$ and positively correlate with $\mathrm{TiO}_{2}$ contents. The estimated $\mathrm{T}$ varies within a wide range of values from $692^{\circ} \mathrm{C}$ to $1106{ }^{\circ} \mathrm{C}$.

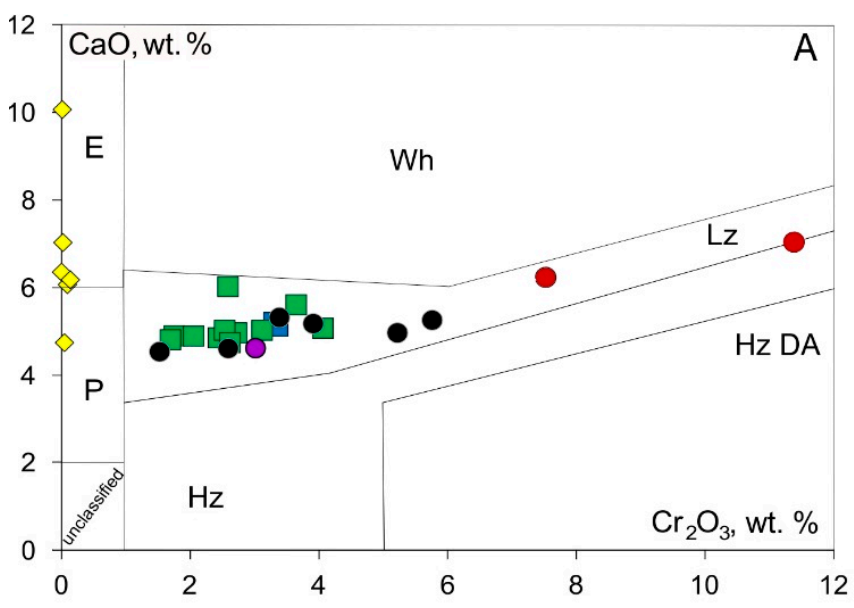

with fractionated MREE-HREE and low MREE

with fractionated MREE-HREE and elevated MREE depleted pyropes from the V. Grib and Mir kimberlite pipes

high-Cr pyropes with "humped" REE from the V. Grib kimberlite pipe

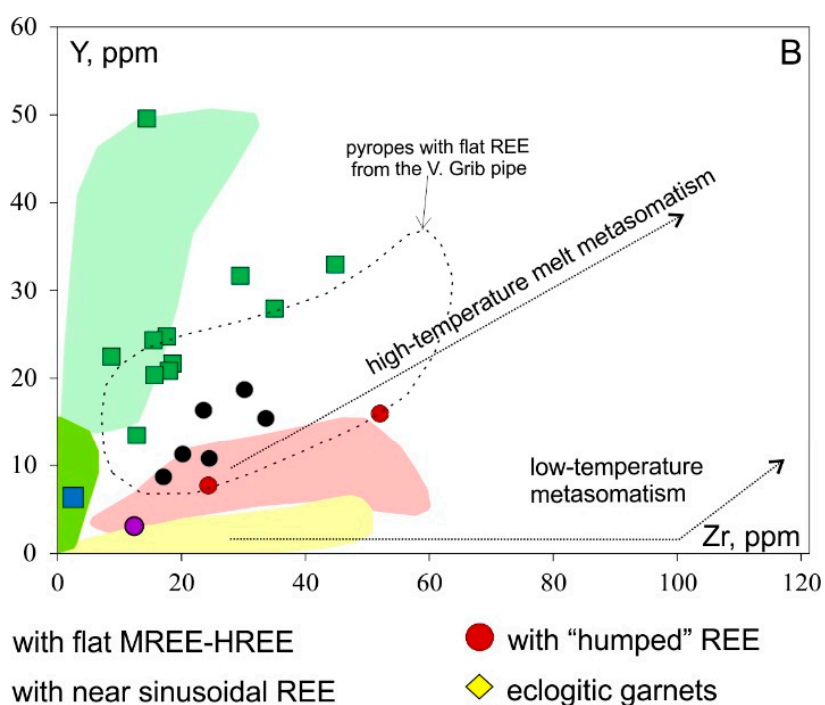

high-Cr pyropes with sinusoidal REE from the V. Grib kimberlite pipe

low-to-middle-Cr pyropes with fractionated REE from the southern areas of Arkhangelsk region

Figure 9. $\mathrm{CaO}-\mathrm{Cr}_{2} \mathrm{O}_{3}(\mathbf{A})$ and $\mathrm{Y} / \mathrm{Zr}(\mathbf{B})$ variations in garnet xenocrysts from the KL-01 pipe. Harzburgite (Hz), Harzburgite diamond association (Hz DA), lherzolite (Lz), wehrlite (Wh) fields, after [30]. Eclogite (E), pyroxenite (P) and "unclassified" fields, after [28]. Pyropes from the V. Grib kimberlite pipe [32,33], Mir kimberlite pipe [34], southern areas of the Arkhangelsk region [3]. Trends of high- and low-temperature metasomatism [36]. M-middle, H—heavy, REE-rare earth element. 

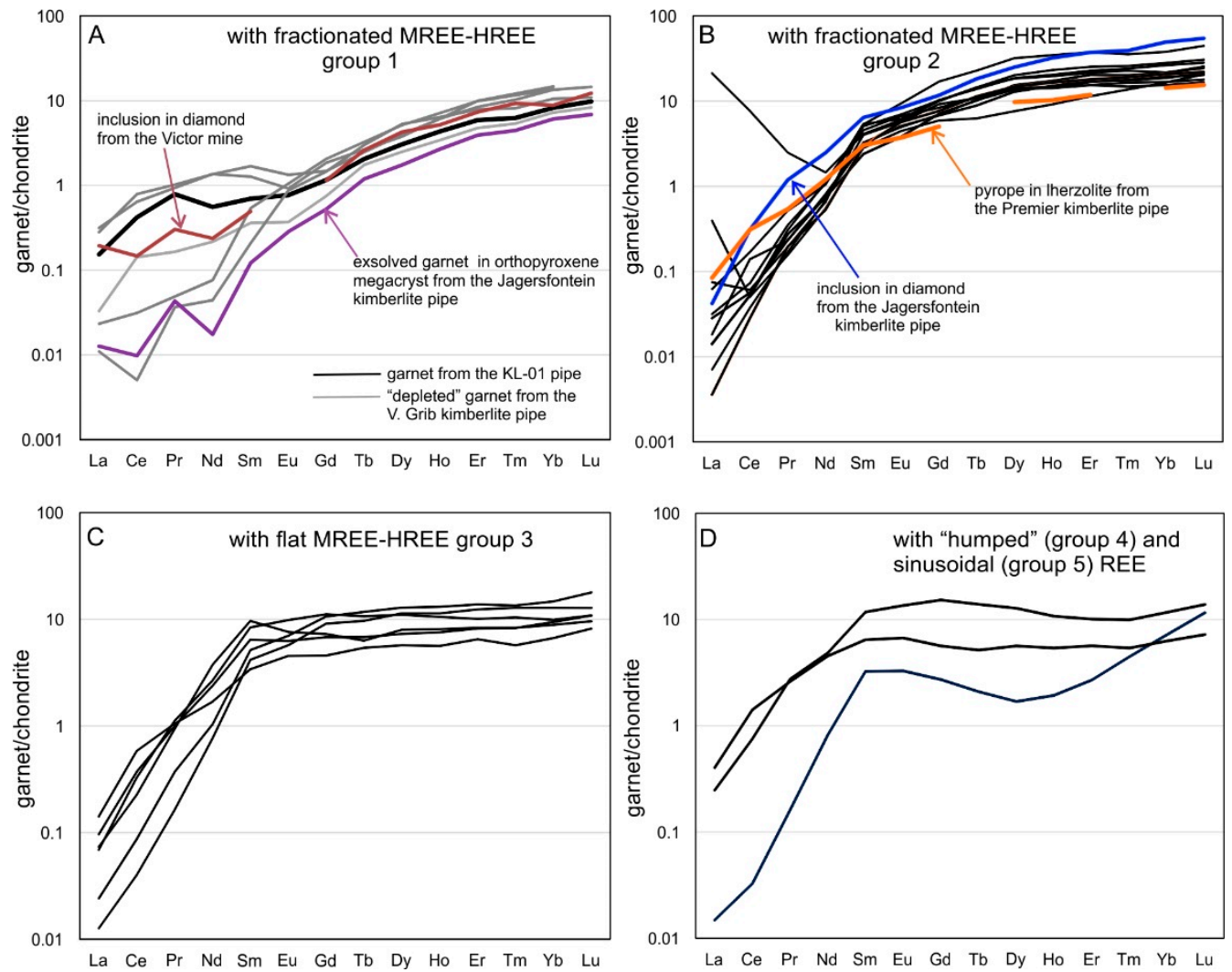

Figure 10. Chondrite-normalized [31] REE patterns of Kl-01 pipe pyrope xenocrysts. (A,B): fractionated MREE-HREE pattern, (C): flat MREE-HREE pattern, (D): "humped" and sinusoidal REE pattern. Pyropes from the V. Grib pipe [32,33], inclusion in diamond from the Victor mine [37], exsolved pyrope in orthopyroxene megacryst from the Jagersfontein [38], inclusion in diamond from the Jagersfontein [39], and pyrope of lherzolite from the Premier pipe [40].

The fourth group ( 2 grains; $9 \%$ ) is represented by pyropes that have "humped" REE patterns with positive slopes from LREEs to MREEs $\left(\mathrm{Sm}_{\mathrm{n}} / \mathrm{La}_{\mathrm{n}}=16\right.$ and 48), peaks at Eu $(7 \times$ chondritic $)$ or $\mathrm{Gd}(15 \times$ chondritic), and negative slopes from MREEs to HREEs with troughs at $\operatorname{Er}(5$ and $10 \times$ chondritic) and positive slopes from $\mathrm{Er}$ to $\mathrm{Lu}(7$ and $14 \times$ chondritic; Figure 10D). Compared to other groups, these pyropes have higher $\mathrm{Hf}_{\mathrm{n}} / \mathrm{Lu}_{\mathrm{n}}$ ratios $(0.8$ and 1$)$ and lower $\mathrm{Y} / \mathrm{Zr}$ ratios $(0.3)$. The pyropes have the highest contents of $\mathrm{Cr}_{2} \mathrm{O}_{3}$ (7.5 and $\left.11.4 \mathrm{wt} . \%\right)$ and $\mathrm{TiO}_{2}(0.35$ and $0.37 \mathrm{wt} . \%)$ compared to other groups. The concentrations of $\mathrm{Ni}$ are 32 and $68 \mathrm{ppm}$, which corresponds to an estimated T of $904^{\circ} \mathrm{C}$ and $1138{ }^{\circ} \mathrm{C}$.

The garnet of the fifth group (one grain; $5 \%$ ) has a nearly sinusoidal REE pattern (Figure 10D). The pyrope is low in $\mathrm{Y}(3 \mathrm{ppm})$ and $\mathrm{Zr}(12 \mathrm{ppm})$ with a $\mathrm{Y} / \mathrm{Zr}$ ratio of 0.3 , similar to garnets with humped REE patterns but has a lower $\mathrm{Hf}_{n} / \mathrm{Lu}_{n}$ ratio (0.2). The pyrope has low $\mathrm{Cr}_{2} \mathrm{O}_{3}(2.9 \mathrm{wt} . \%)$ and $\mathrm{minor}^{\mathrm{TiO}} 2$ (0.09 wt.\%) contents. The concentration of $\mathrm{Ni}$ is $11 \mathrm{ppm}$, which corresponds to an estimated $\mathrm{T}$ of $675^{\circ} \mathrm{C}$.

\subsubsection{Chromium Spinel}

Sixteen grains of spinel group minerals have $\mathrm{Cr} /(\mathrm{Cr}+\mathrm{Al})>0.5(\mathrm{Cr} \#$; molar $)$ and are chromium spinel; five grains with $\mathrm{Fe}^{2+} /\left(\mathrm{Fe}^{2+}+\mathrm{Mg}\right)>0.5$ are chromites; and 11 grains with $\mathrm{Fe}^{2+} /\left(\mathrm{Fe}^{2+}+\mathrm{Mg}\right)<0.5$ are magnesio-chromites [41]. Based on the major element compositions (Table S4-2 in Supplementary Material), chromium spinels may be divided into three main groups. The first group ( 5 grains; $32 \%$ ) is represented by magnesio-chromites with $0.65<\mathrm{Cr} \#<0.72$. These grains have the lowest concentrations of $\mathrm{TiO}_{2}(0.1-0.3 \mathrm{wt} . \%)$ and $\mathrm{NiO}\left(0.04-0.08\right.$ wt.\%) and estimated temperature values of $640-680^{\circ} \mathrm{C}$ based on the $\mathrm{Zn}$ thermometer [35]. The second group ( 9 grains; $56 \%$ ) consists of magnesio-chromites 
and chromites with $0.87<\mathrm{Cr} \#<0.92$, which contain more $\mathrm{TiO}_{2}(1-1.8$ wt.\%) and $\mathrm{NiO}$ (0.06-0.12 wt.\%) and have higher values of $\mathrm{T}\left(740-963^{\circ} \mathrm{C}\right)$ than those of the first group. The third group $(12 \%)$ combines two grains of chromites with $0.89<\mathrm{Cr} \#<0.91$, which also have the highest contents of $\mathrm{TiO}_{2}(2.9-3.4 \mathrm{wt} . \%)$. The $\mathrm{NiO}$ content $(0.11 \mathrm{wt} . \%)$ and estimated $\mathrm{T}$ $\left(830-840{ }^{\circ} \mathrm{C}\right)$ are within the range of group 2 . On discrimination diagrams (Figure 11), the compositions of all chromium spinel grains match those from the Arkhangelskaya [16] and V. Grib kimberlite pipes (Table S5-1 in Supplementary Material). The low-chromium $\left(\mathrm{Cr}_{2} \mathrm{O}_{3}\right.$ $<54$ wt.\%), low-titanium $\left(\mathrm{TiO}_{2}<1\right.$ wt.\%) spinels from the KL-01 and Arkhangelskaya pipes match those found in the crater sample of the Suksoma melilitite/picrite pipe (Figure 11).
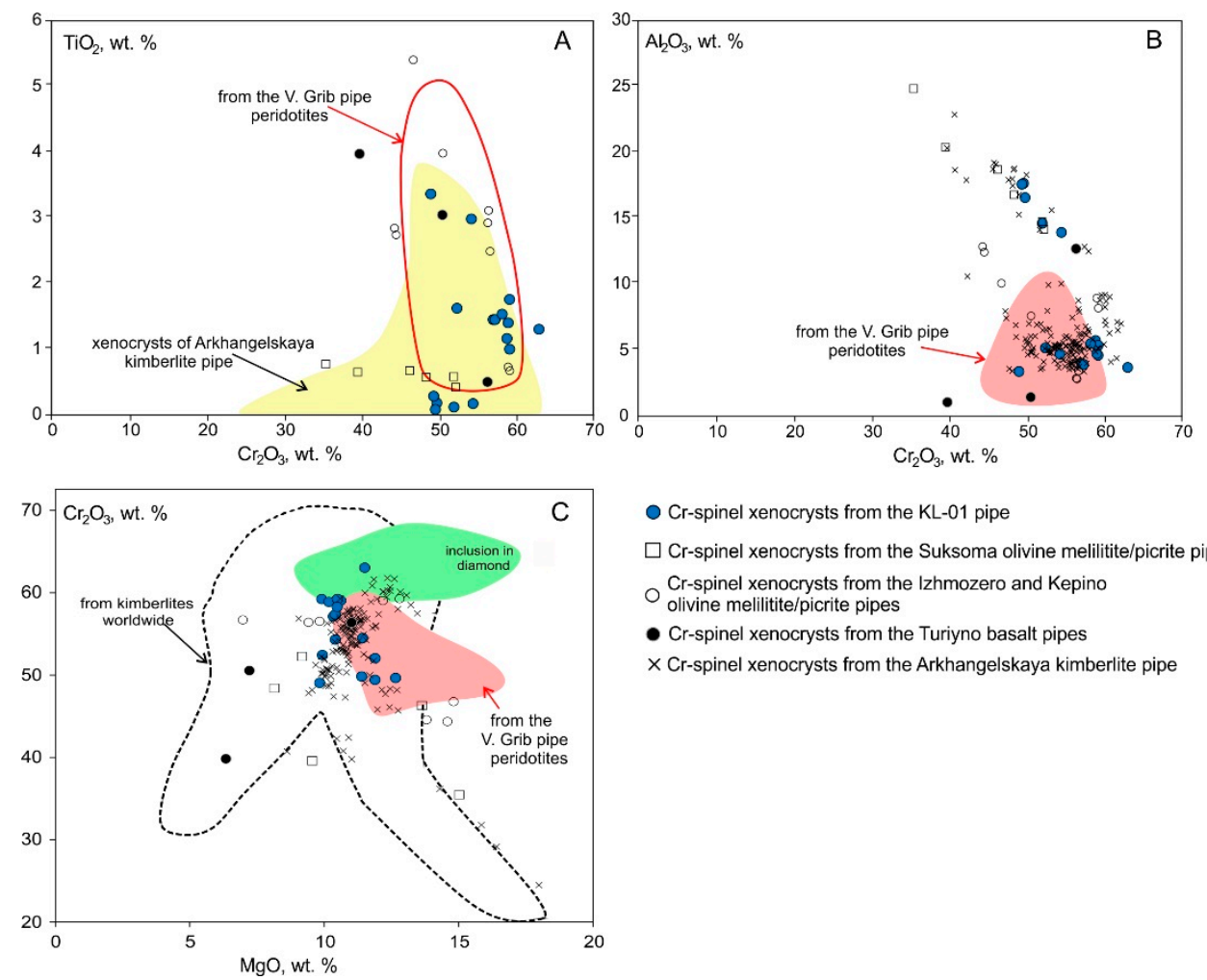

\footnotetext{
- Cr-spinel xenocrysts from the KL-01 pipe

$\square$ Cr-spinel xenocrysts from the Suksoma olivine melilitite/picrite pipe

Cr-spinel xenocrysts from the Izhmozero and Kepino

olivine melilitite/picrite pipes

- Cr-spinel xenocrysts from the Turiyno basalt pipes

$\times$ Cr-spinel xenocrysts from the Arkhangelskaya kimberlite pipe
}

Figure 11. $\mathrm{TiO}_{2}-\mathrm{Cr}_{2} \mathrm{O}_{3}(\mathbf{A}), \mathrm{Al}_{2} \mathrm{O}_{3}-\mathrm{Cr}_{2} \mathrm{O}_{3}(\mathbf{B})$ and $\mathrm{Cr}_{2} \mathrm{O}_{3}-\mathrm{MgO}(\mathbf{C})$ relation diagrams for Cr-spinel xenocrysts from the KL-01 pipe. Cr-spinel xenocrysts from the Arkhangelskaya pipe [16]; from the Izhmozero and Kepino olivine melilitite/picrite pipes [9]; from the V. Grib pipe peridotites (Table S5-1 in Supplementary Material), Suksoma and Turiyno field pipes [9]. Fields for Cr-spinel from the kimberlites worldwide and diamond inclusions [42].

\subsubsection{Magnesian Ilmenite}

Eight grains of ilmenite are classified as magnesian ilmenite with high $\mathrm{MgO}(10-13 \mathrm{wt} . \%)$, moderate $\mathrm{TiO}_{2}$ (51.7-54.2 wt.\%) and low $\mathrm{Fe}_{2} \mathrm{O}_{3 \text { calc }}$ (4.7-9.1 wt.\%) contents and correspond to the "kimberlite" type of ilmenite [43]. The concentrations of major oxides (Table S4-3 in Supplementary Material) are within the ranges of those from ADP kimberlites (Figure 12A), and their variations (Figure 12B,C) indicate that the KL-01 pipe ilmenites clearly differ from those from the Stepnaya [44] and Grib kimberlite pipes (Table S5-2 in Supplementary Material) and overlap with the Tsingri-Arkhangelskaya (Table S5-3 in Supplementary Material) and Arkhangelskaya [16] kimberlite pipes ilmenites. 

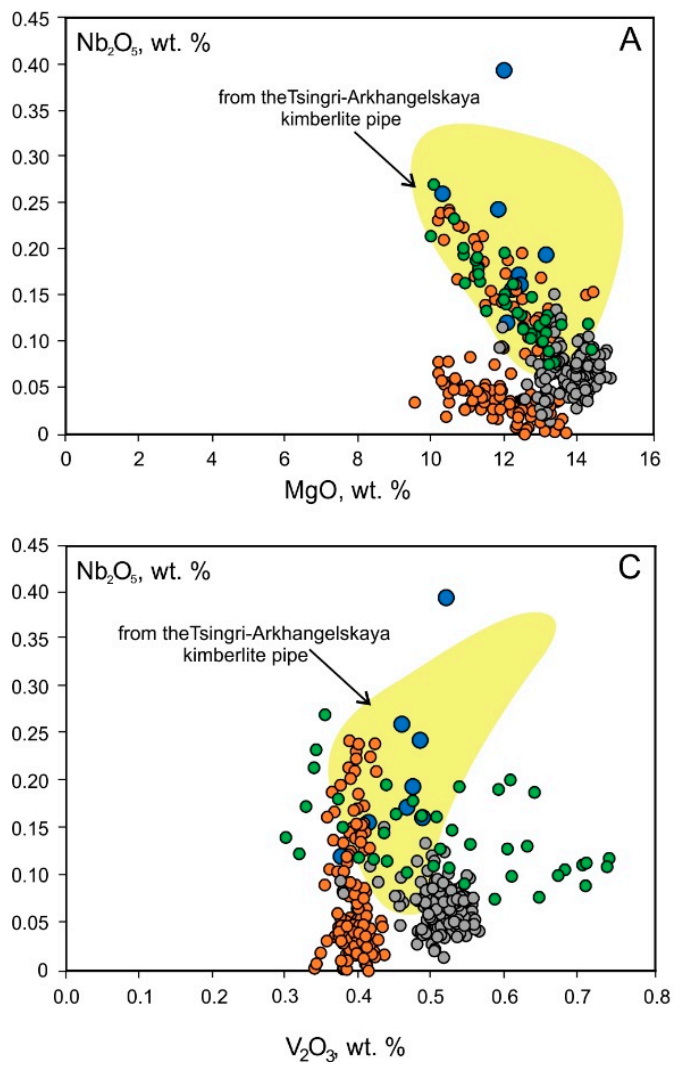

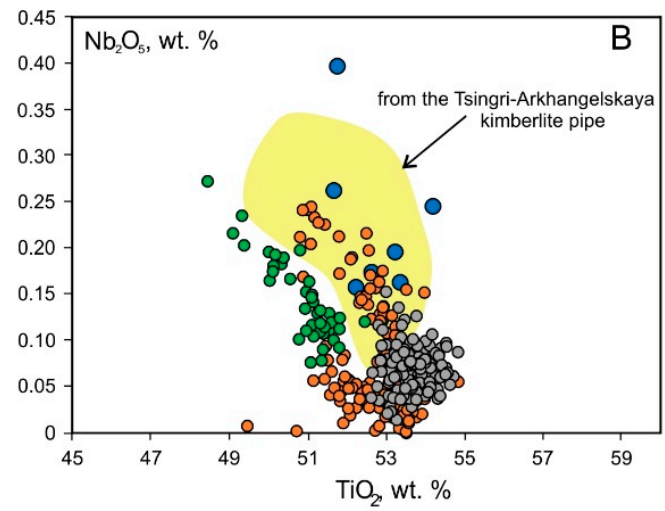

Mg-ilmenite xenocrysts from the KL-01 pipe

O Mg-ilmenite xenocrysts from the V. Grib kimberlite pipe

OMg-ilmenite xenocrysts from the Arkhangelskaya kimberlite pipe

Mg-ilmenite xenocrysts from the Stepnaya kimberlite pipe

Figure 12. $\mathrm{Nb}_{2} \mathrm{O}_{5}-\mathrm{MgO}(\mathbf{A}), \mathrm{Nb}_{2} \mathrm{O}_{5}-\mathrm{TiO}_{2}(\mathbf{B})$ and $\mathrm{Nb}_{2} \mathrm{O}_{5}-\mathrm{V}_{2} \mathrm{O}_{3}(\mathbf{C})$ relation diagrams for $\mathrm{Mg}$-ilmenite xenocrysts from the KL-01 pipe. Mg-ilmenite xenocrysts from the Arkhangelskaya pipe [16]; from Stepnaya kimberlite pipe [44]; from the Tsnigri-Arkhangelskaya and V. Grib kimberlite pipes (Tables S5-2 and S5-3 in Supplementary Material).

\subsubsection{Olivine and Chromium Diopside}

Two olivine grains were selected directly from the greenish segregations in sample KL01-2-144.3 (Figure 4). These olivines are identical in composition and have high Mg\# (92.4) and moderate $\mathrm{NiO}(0.36 \mathrm{wt} . \%)$ contents (Table S4-4 in Supplementary Material). In discrimination diagrams, the olivines match the fields of those from kimberlites and mantle peridotites of the Lomonosov and Grib deposits [32,45-48] (Figure S4 in Supplementary Material).

Four grains of clinopyroxene are diopsides with high $\mathrm{Cr}_{2} \mathrm{O}_{3}$ contents $(0.65-2.05$ wt.\%) and can be classified as chromium diopside. One grain has $\mathrm{Al}_{2} \mathrm{O}_{3}$ (6.1 wt.\%) and low $\mathrm{Mg \#}$ (89.0) and plots in the field of "spinel peridotite and off-craton garnet peridotites" [49] (Figure S5 in Supplementary Material). The other three grains have high Mg\# (92.6-94.9), match the field of "on-craton garnet peridotites" and have compositions similar to those from the Lomonosov and Grib kimberlites and garnet peridotites. Based on the $\mathrm{Ca} / \mathrm{Al}$ ratio, one grain could have been derived from within the diamond stability field, whereas another grain could have been derived from the graphite stability field [50]. None of the grains has a composition suitable for P-T calculation [51,52].

\section{Discussion}

\subsection{Smectite Group Minerals as Kimberlite Indicators within the Arkhangelsk} Diamondiferous Province

Smectite minerals, including dioctahedral montmorillonite and trioctahedral saponite, are common secondary phases in kimberlites [53] and one of the dominant components in kimberlite weathering [54-56]. Smectite minerals found within the ADP are limited to three options: (1) within the crater and diatreme parts of magmatic pipes; (2) in the Ven- 
dian sandstones bordering the kimberlite pipes; and (3) within the middle Carboniferous sandstones of the Urzuga Formation.

Saponite is the most abundant smectite mineral in the ADP magmatic pipes. It is always present within the crater sediments of kimberlite and melilitite/picrite pipes and a typical component of their diatreme xeno-tuff breccias. In the V. Grib kimberlite pipe, saponite is identified within the whole spectra of crater sediments, as well as within the xeno-tuff breccia diatreme zone and near the level of the kimberlite crater/diatreme contact [4], whereas diatreme kimberlite is rich in serpentine, with no smectite minerals. In the V. Grib pipe crater sediments, saponite is present mostly in the form of oval segregations, usually interpreted as pseudomorphs after olivine grains, veins and shapeless chaotic formations, as well as in the groundmass together with carbonate and hydromica; rare saponite replaces pyrope grains [4]. In the Arkhangelskaya kimberlite pipe, saponite is ubiquitously abundant. It forms oval segregations and veins in the crater sediments, intensively replaces KIM xenocrysts and the constituent minerals of mantle xenoliths and is the main mineral in the groundmass of kimberlite and kimberlite itself [12]. The saponite modes vary within the range of $1-60 \mathrm{vol} . \%$ in crater sediments and $60-90$ vol. $\%$ in diatreme kimberlite, whereas serpentine is minor in the diatreme part ( $<40 \mathrm{vol} . \%)$ and completely absent in the crater part [12]. Unusual quartz grains have also been documented [55] in the crater parts and upper levels of the ADP kimberlite pipes. This quartz is partly or fully altered to saponite, which is the main difference from quartz in the country rocks, and is called "pipe quartz" [55,56].

Montmorillonite is a much less common smectite mineral in the ADP magmatic pipes. It, together with hydromica, has previously been documented in the depth range of 20-70 m within the crater sediments of the Arkhangelskaya kimberlite pipe [12,55] and near the contact of the crater with the overlying Paleozoic sediments in the Karpinskogo-2 pipes [57]. Our study also shows the presence of montmorillonite in the V. Grib pipe crater sandstones, which contain $20<\mathrm{MM}<40 \mathrm{vol} . \%$, and the lack of montmorillonite in the studied crater samples of the Kepino kimberlites.

The ubiquitous formation of smectite minerals in the ADP magmatic pipes, especially kimberlites, is primarily associated with the long-term influence of hydrothermal processes, which were promoted by the specific composition of the country rock sandstones, which are weakly cemented and therefore easily permeated by groundwater $[12,56,58]$. The crater sediments of the ADP kimberlites are reddish-brown or rusty colored and contain abundant sandstone components and very low numbers of KIMs and smectite minerals as the main phases found in altered MM. The rocks change dramatically in the transitional zone from the crater to the diatreme part, near 160 and 170-180 m from the surface for Arkhangelskaya [12] and V. Grib (our data) kimberlite pipes, respectively. The rocks become gray, greenish-gray and green colored with a gradually decreasing and completely disappearing sandstone component, an increasing number of unaltered KIMs and the appearance of serpentine as subordinate to smectite (for the Arkhangelskaya pipe) or as the main secondary mineral (for the V. Grib pipe) in kimberlite. These differences can also indicate oxidizing conditions for crater sediments, favorable conditions for smectite formation and reducing conditions for diatreme rocks [12].

Smectite minerals have also been previously observed within the country rock Vendian sandstones, which are bordered by kimberlite pipes [59]. Smectites form numerous subhorizontal veins in sandstone cracks and are traced within a maximum of five meters from the border with the pipe [59]. However, smectite segregations are also documented in the form of rare vertical veins in the Vendian sandstones in boreholes at distances of $20 \mathrm{~m}$ and $100 \mathrm{~m}$ from the edge of the Arkhangelskaya pipe [59].

Finally, smectite minerals are found within the middle Carboniferous sandstones of the Urzuga Formation $[12,57,59]$, which are regarded as the main secondary deposits for the ADP KIMs and diamonds. These sandstones cover three quarters of the ADP area and unconformably overlie the Vendian rocks; they are also observed within the sediments covering the majority of pipes [57]. Smectites have been documented to form 
oval segregations within the five-meter lower layer of Urzuga sandstones that cover pipes and chaotic fine-grained segregations outside of pipes [59]. The concentrations of KIMs in the Urzuga sandstones located within $1 \mathrm{~km}$ outside of kimberlite pipes are well established to be much higher for pipes with no crater part than for pipes with preserved craters [57]. Additionally, the numbers of KIMs found in the secondary deposits primarily depend on the type and thickness of rocks overlying the pipe and secondarily on the initial concentrations of KIMs in the pipe. The majority of the ADP kimberlites and all olivine melilitites/picrites contain low numbers of KIMs, with the exception of the highdiamondiferous V. Grib kimberlite and several low-diamondiferous Kepino kimberlites (e.g., pipes no. 688 and no. 697, Tsnigri-Arkhangelskaya and Soloha [21]). In this case, the identification of smectite minerals, especially saponite, together with even one KIM grain that has a surface with no signs of mechanical abrasion (usually, the location of such grains is limited to within 1-2 km from the pipe) is proposed for use as one of the methods of identifying kimberlite pipes within the region $[56,60]$.

The sandstones of the KL-01 pipe contain smectites mostly in the form of oval segregations that are $0.2-2 \mathrm{~cm}$ in size. Their modes are maximum in the depth ranges of $170-250 \mathrm{~m}$ for BRH-1 (10 vol. \%) and 140-150 m for BRH-2 (30 vol.\%). The smectite distribution within the rocks is not random, but few of them take the form of veins. Additionally, the thicknesses of sandstones that contain smectite segregations vary within the depth range of $70-80 \mathrm{~m}$ in the two boreholes. These observations demonstrate that the KL-01 sandstones are unlikely to represent an area of country rock sandstones on the border with the pipe or secondary deposits. Similar to sandstones composing the crater parts of ADP pipes, the majority of oval greenish smectite formations can be interpreted as pseudomorphs after constituent minerals of some magmatic rocks. The alteration of quartz grains to smectites is possible, but only for pseudomorphs with sizes similar to those of sandstone quartz $(<1 \mathrm{~mm})$. Additionally, there are smectite segregations up to seven $\mathrm{cm}$ in size (e.g., sample KL01-2-144.3, Figure 4J), from which two fresh high-Mg olivine grains were hand-picked, which can also indicate alteration of mantle xenoliths. The sandstones of the KL-01 pipe can be proposed to represent the crater part of a pipe. These sandstones may be assumed to be predominantly components of the upper level of the crater if they are analogous to the distribution of montmorillonite in the craters of the ADP pipes. If this is true, the lower boundary of the crater may be deeper than $300 \mathrm{~m}$ from the surface, and the thickness is at least $160 \mathrm{~m}$.

\subsection{Evaluation of the Type of Magmatic Material Admixture in the KL-01 Pipe}

An attempt to identify the type of MM in the KL-01 sandstones is made in this section. Subsequently, a model of binary mixing of the compositions of Vendian sandstones with known ADP magmatic rocks is used. The end-members of mixing are chosen based on the main geochemical differences among ADP magmatic rocks, as described in Section 3 (Table S6). To exclude crustal contamination the average compositions of hypabyssal samples of the ADP magmatic rocks were used [61-63].

The modeling based on the correlations of major oxides (Figure 13A) or the combination of major oxides with trace elements (Figure 13B) or with their ratios (Figure 13C) shows that the mixing trends mostly overlap or are close to each other. The V. Grib pipe and the KL-01 sandstones simultaneously match different types of rocks, but the V. Grib pipe sandstones with $\mathrm{MM}>40$ vol.\% sometimes match the V. Grib kimberlite mixing trend. To obtain more clarity, a mixing model based on the correlation of a limited set of elements and ratios, namely, $\mathrm{La} / \mathrm{Yb}, \mathrm{Zr} / \mathrm{Nb}$ and $\mathrm{Ni}$, which are very specific for the ADP magmatic rocks, and a step-by-step approach is proposed.

\section{Step 1. Excluding the Admixture of Carbonatite and Carbonatized Kimberlite Component}

These types of rocks can be excluded as possible candidates for MM merely by using the correlation of $\mathrm{La} / \mathrm{Yb}$ with $\mathrm{Ni}$ content (Figure 14A). The addition of $10 \mathrm{vol} \%$ carbonatite to the calculation gives a $\mathrm{La} / \mathrm{Yb}$ ratio two to three times higher than those of other ADP magmatic rocks, and $\mathrm{Ni}$ does not exceed $17 \mathrm{ppm}$. The addition of a greater carbonatite 
component leads to an increase in the ratio of $\mathrm{La} / \mathrm{Yb}$ to $\mathrm{Ni}$ from a maximum of 1.2 to 2 at $\mathrm{Ni}$ variations of $10-135 \mathrm{ppm}$, whereas the same ratio for other ADP magmatic rocks decreases from 0.8 to 0.02 with increasing addition of the MM component. The trend of mixing with carbonatized kimberlite occupies a transitional position between carbonatite and other ADP magmatic rocks (Figure 14A) but differs from the latter due to the higher ratios of $\mathrm{La} / \mathrm{Yb}$ to $\mathrm{Ni}$, varying from 0.4 to 0.2 at $\mathrm{Ni}$ contents of $28-485 \mathrm{ppm}$.
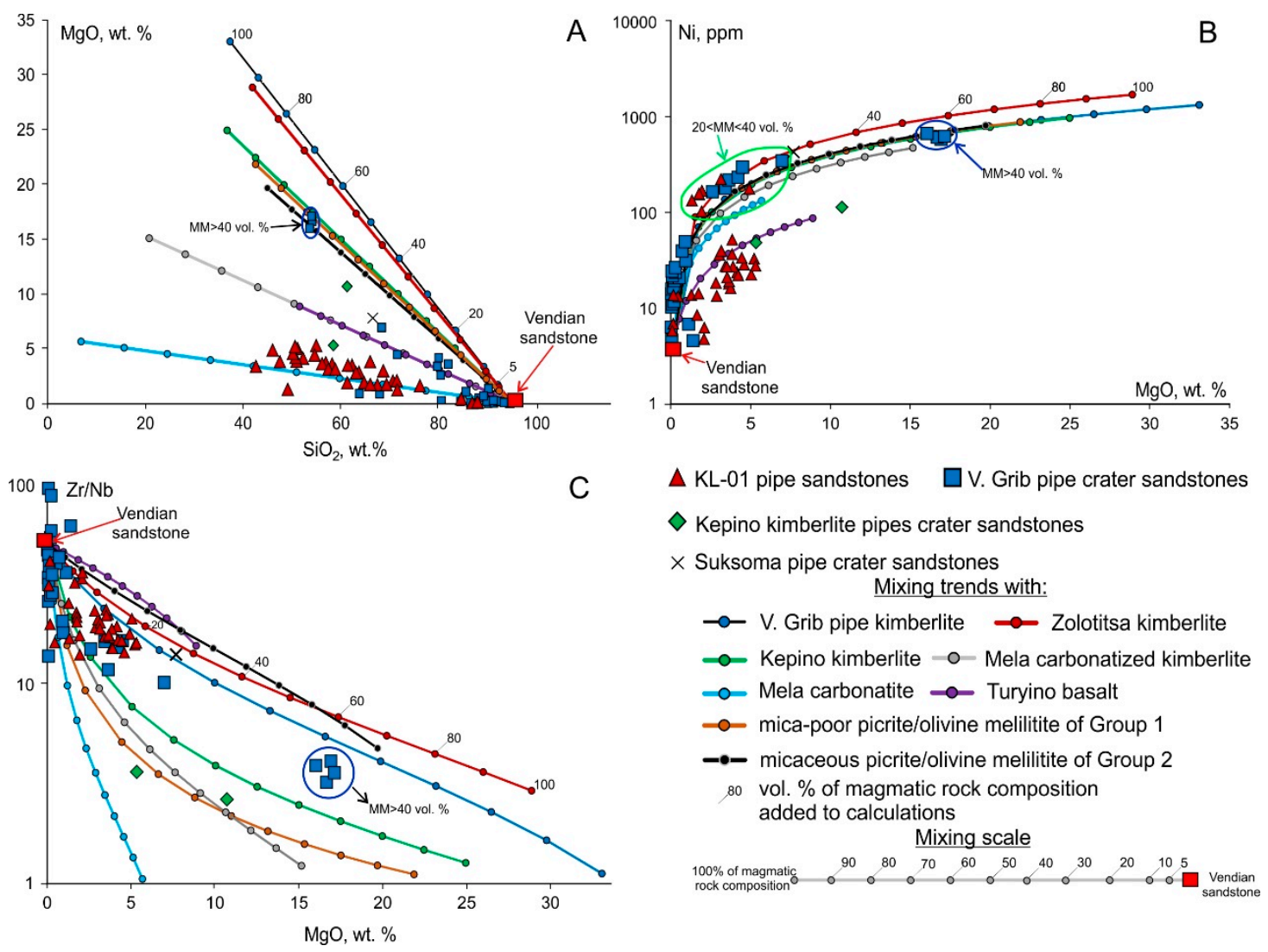

Figure 13. Trends of binary mixing between Vendian sandstones and typical ADP magmatic rocks based on correlations of $\mathrm{MgO}-\mathrm{SiO} 2$ (A), $\mathrm{Ni}-\mathrm{MgO}$ (B) and $\mathrm{Zr} / \mathrm{Nb}-\mathrm{MgO}(\mathbf{C})$. The end-members of mixing are the average compositions of Vendian sandstones and typical ADP magmatic rocks (Table S6).

\section{Step 2. Excluding the Admixture of the Basalt Component}

The trend of mixing with the basalt component is always near or overlaps those of the ADP kimberlites and melilitites/picrites (Figure 13) but differs by showing significantly smaller ranges of variations for all components, especially $\mathrm{MgO}, \mathrm{Ni}$ and $\mathrm{Cr}$, and $\mathrm{Zr} / \mathrm{Nb}$ ratios. The best way to exclude the admixture of the basalt component is to use the value of $\mathrm{Ni}$ content. If the $\mathrm{Ni}$ content is higher than the maximum $\mathrm{Ni}$ concentration in basalts, i.e., $>90 \mathrm{ppm}$, and the volume percentage of the sandstone component is greater than that of the MM in the studied rocks, then the basalt admixture can be ruled out.

\section{Step 3. Excluding the Admixture of Micaceous Picrite/Olivine Melilitite of the Group 2 Component}

The trend of mixing with this type of rock is close to those with the Zolotitsa and V. Grib kimberlites (Figures 13 and 14B), where the main difference from the latter lies in different values of the concentrations of one or another element or ratio with the same addition of the MM component. For example, the addition of 40 and 60 vol.\% micaceous picrites/olivine melilitites of the Group 2 component into the calculations gives $\mathrm{Zr} / \mathrm{Nb}$ ratios and $\mathrm{Ni}$ contents equal to the addition of 20 and $30 \mathrm{vol}$ \% Zolotitsa or V. Grib kimberlite components, respectively. Therefore, the juxtaposition of data on MM modes with the 
$\mathrm{Ni}$ content and the $\mathrm{Zr} / \mathrm{Nb}$ ratio is the best way to exclude the micaceous picrites/olivine melilitites of Group 2 as the MM admixture; i.e., if the volume percentage of $\mathrm{MM}$ in the studied rocks is significantly lower (by 20-30 vol.\%) than those indicated in the $\mathrm{Zr} / \mathrm{Nb}$ versus Ni diagram, this type of rock can be ruled out as an MM admixture.
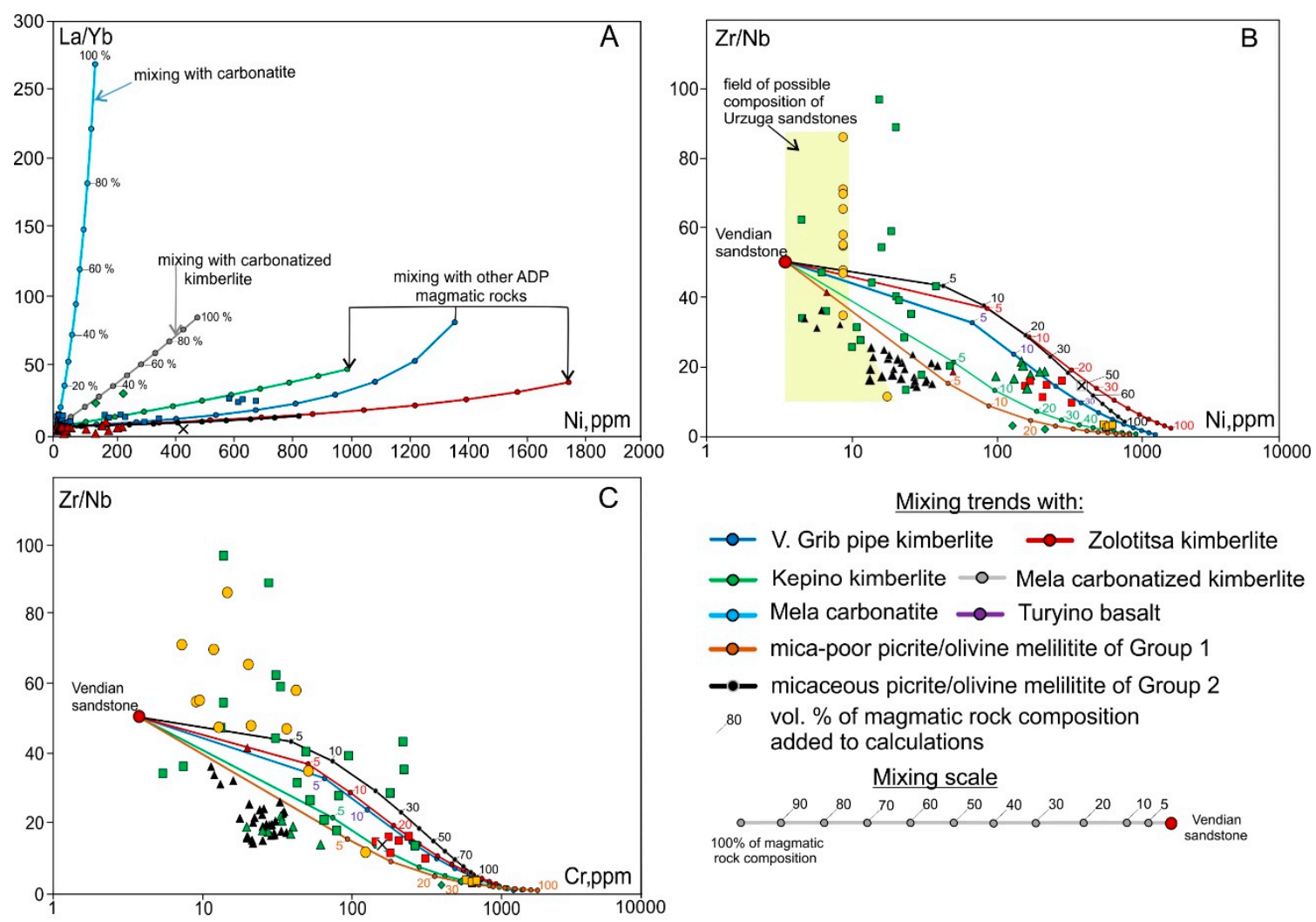
$\Delta \mathrm{KL}-01$ pipe sandstone $\square$ V. Grib pipe crater sandstone
$\times$ Suksoma pipe crater sandstone
- Vendian sandstone
Kepino kimberlite pipes crater sandstone
$\triangle \mathrm{KL}-01$ pipe sandstone with $20<\mathrm{MM}<30$ vol. $\%$
$\mathrm{KL}-01$ pipe sandstone with $\mathrm{MM}<20$ vol. \%
V. Grib pipe crater sandstone with $\mathrm{MM}<20$ vol. \%
V. Grib pipe crater sandstone with $20<\mathrm{MM}<40$ vol. $\%$
Urzuga sandstone
V. Grib pipe crater sandstone with $M M>40$ vol. \%

Figure 14. Trends of binary mixing between Vendian sandstones and typical ADP magmatic rocks based on correlations of $\mathrm{La} / \mathrm{Yb}-\mathrm{Ni}(\mathbf{A}), \mathrm{Zr} / \mathrm{Nb}-\mathrm{Ni}(\mathbf{B})$ and $\mathrm{Zr} / \mathrm{Nb}-\mathrm{Cr}(\mathbf{C})$. The end-members of mixing are the average compositions of Vendian sandstones and typical ADP magmatic rocks.

\section{Step 4. Choosing the Type of MM Admixture}

If the types of ADP magmatic rocks described above as MM admixtures have been ruled out in steps $1-3$, using the $\mathrm{Zr} / \mathrm{Nb}$ values and $\mathrm{Ni}$ contents is the only right way to identify the type of MM admixture (Figure 14B). The mixing trends allow us to identify the area of mixing with the kimberlite component and to make an assumption about the type of ADP kimberlite (Kepino, Zolotitsa or V. Grib kimberlites) added to the mixture. However, it is impossible to differentiate the Kepino kimberlite and mica-poor picrites/olivine melilitites of Group 1 as MM admixtures. Although these rocks have clear differences in $\mathrm{Mg \#} \mathrm{(0.82} \mathrm{in} \mathrm{kimberlite} \mathrm{versus} 0.74$ in picrite/olivine melilitite), La/Yb ratios (48 versus 22) and $\mathrm{SiO}_{2}$ (36.7 versus $42.6 \mathrm{wt} . \%$ ) and $\mathrm{FeO}$ (9.6 versus $13.4 \mathrm{wt} . \%$ ) contents, the other geochemical features are similar. The mixing trends based on $\mathrm{Mg \#}, \mathrm{SiO}_{2}$ and $\mathrm{FeO}$ do not provide any clarity due to the significant influence of the sandstone component in the calculations [61-63]. Thus, one can only assume in favor of one or another type of rock as the MM admixture, for example, according to the type of the most common mantle mineral 
from the heavy fraction; if spinel group minerals prevail, then the MM admixture can be defined as predominantly picrite/olivine melilitite; if pyrope and Mg-ilmenite dominate, then the MM is kimberlite.

Model Verification using the Natural Samples

In the $\mathrm{Zr} / \mathrm{Nb}$ versus $\mathrm{Ni}$ diagram, the composition of sandstone from the crater of the Suksoma pipe clearly matches the calculated mixing trend to overlap with the MM modes ( 50 vol. $\%$; Figure 14B). The sandstone compositions in the crater parts of the Kepino kimberlites match the area near the calculated mixing trend with mica-poor picrites/olivine melilitites of Group 1, confirming the geochemical similarities and the impossibility of differentiating these types of rocks as the MM component. The sandstones from the crater of the V. Grib kimberlite pipe show two main positions on the $\mathrm{Zr} / \mathrm{Nb}$ versus $\mathrm{Ni}$ diagramthose with $<20$ vol.\% MM are randomly located on the diagram with no clear correlations; and those with $20<\mathrm{MM}<40$ vol. $\%$ and $\mathrm{MM}>40$ vol. $\%$ match the area near the calculated mixing trend with the V. Grib kimberlite, as well as having similarity in the vol.\% of calculated and observed MM. The sandstones of the KL-01 pipe from BRH-2 sampled within the depth range of 140-150 m, which contain 20-30 vol.\% MM, match the area between the calculated mixing trends with the Kepino and V. Grib kimberlites, mostly grouped next to or overlapping with the latter. Other KL-01 samples with $\mathrm{MM}<20$ vol.\% mostly lie outside of the calculated mixing trends or match the area of mixing with the addition of $M M<5$ vol. $\%$, similar to the V. Grib pipe sandstones with $M M<20$ vol. $\%$.

The verification of the proposed model shows that the type of MM in the ADP sandstones can be identified only for the samples that contain $>20$ vol.\% MM. The compositions of sandstones that contain $<20 \mathrm{vol} . \% \mathrm{MM}$ cannot provide any information about the type of MM admixture but can be used to distinguish them from the middle Carboniferous sandstones of the Urzuga Formation, which is of tremendous importance when test drilling targets within the ADP. The $\mathrm{Zr} / \mathrm{Nb}$ ratios vary within a wide range of values from 12 to 87 , whereas Ni does not exceed $20 \mathrm{ppm}$ in the Urzuga sandstones (Figure 14B). The $\mathrm{Cr}$ contents in the Urzuga sandstones also have a wide range from 7 to $130 \mathrm{ppm}$, and the maximum values are close to those in the sandstones from the V. Grib and Suksoma pipes, which contain MM > 20 vol. \% and 50 vol.\%, respectively (Figure 14C). Therefore, distinguishing any sandstones with $\mathrm{MM}$ admixtures from the Urzuga suite cannot be done by using the $\mathrm{Cr}$ contents. The fact that the data on $\mathrm{Cr}$ contents calculated in the model and in real ADP crater samples do not coincide should also be considered. Additionally, the set of V. Grib pipe crater samples with MM < 20 vol.\% have high Cr contents (190-280 ppm), which are not correlated with MM modes, Ni contents or $\mathrm{Zr} / \mathrm{Nb}$ ratios (Figure 14C). The $\mathrm{V}$. Grib pipe crater sandstones with $20<\mathrm{MM}<40 \mathrm{vol} . \%$ and $\mathrm{MM}>40 \mathrm{vol} \%$ show positive correlations of $\mathrm{Ni}$ and $\mathrm{Cr}$, whereas the KL-01 samples do not, and this observation cannot be ignored. One of the explanations for the low chromium contents of the KL-01 samples may be the extremely low numbers of KIMs in the samples.

\subsection{The KIM Composition as the Key to Evaluating the Thermal State, Composition and Metasomatic Evolution of the Lithospheric Mantle Sampled using the KL-01 Pipe}

All grains of KIMs recovered from the sandstones of the KL-01 pipe have primary magmatic surfaces with no signs of mechanical or intense chemical abrasions and therefore can be interpreted as fragments of mantle rocks sampled and transported by the KL-01 pipe. Thus, the interpretation of the KIMs can provide some information about the composition and thermal state of the lithospheric mantle beneath the KL-01 pipe.

\subsubsection{Thermal State of the Lithospheric Mantle}

Based on the available data obtained from the KL-01 pipe KIMs, there are two ways to obtain information about the thermal state of the lithospheric mantle: (1) to project the equilibrium $\mathrm{T}_{\mathrm{Ni}}$ for pyropes onto the "average" ADP geotherm and (2) to calculate the pressure parameter for pyrope using the method of [35], assuming that pyropes were in equilibrium with coexisting chromite (Figure 15A). Previous studies on the thermal 
state of the ADP lithospheric mantle $[16,32,33,64]$ show that the geotherm estimates are mostly between 35 and $40 \mathrm{~mW} / \mathrm{m}^{2}$ at pressures of $40-75 \mathrm{kbar}$ and $37-40 \mathrm{~mW} / \mathrm{m}^{2}$ (up to $45 \mathrm{~mW} / \mathrm{m}^{2}$ in [64]) at pressures of $20-40$ kbar. Projecting the $\mathrm{T}_{\mathrm{Ni}}$ for the KL-01 pyropes onto the $37 \mathrm{~mW} / \mathrm{m}^{2}$ heat flow and considering the possible range of variations in the heat flux values at the pressure ranges indicated above (Figure 15B) shows that four pyrope grains ( $19 \%$ of the total lherzolite population) could have originated from the diamond stability field at depths of 150-190 km; two grains (9.5\%) from near the graphite-diamond stability field boundary at $\sim 120 \mathrm{~km}$; and 15 grains $(71.5 \%)$ from the graphite stability field at depths ranging from $60-100 \mathrm{~km}$. The values of estimated P-T parameters for pyropes obtained by the method of [35] mostly match the area of possible P-T variations, with the exceptions of pyropes equilibrated at $\mathrm{T}>1100^{\circ} \mathrm{C}$ (Figure 15B). The lower boundary of the sampled lithospheric mantle can be concluded to lie in the depth range of 175-190 km with a diamond window width of $55-70 \mathrm{~km}$.

\section{A}

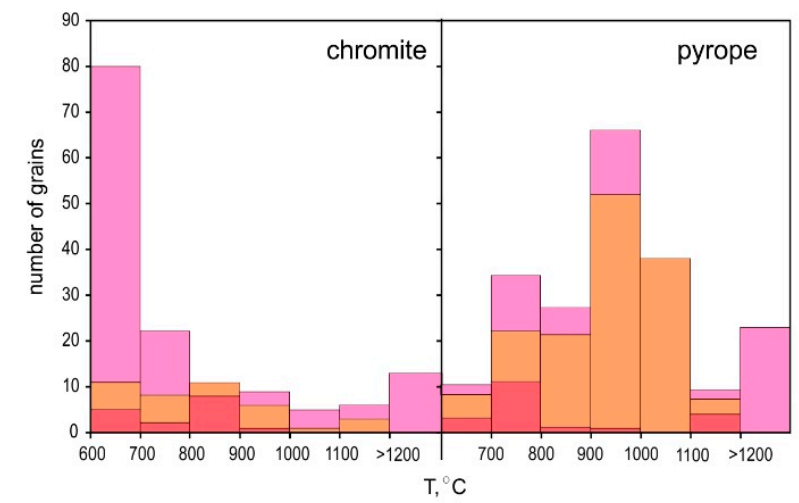

KL-01 pipe V. Grib pipe $\quad$ Arkhangelskaya pipe

B

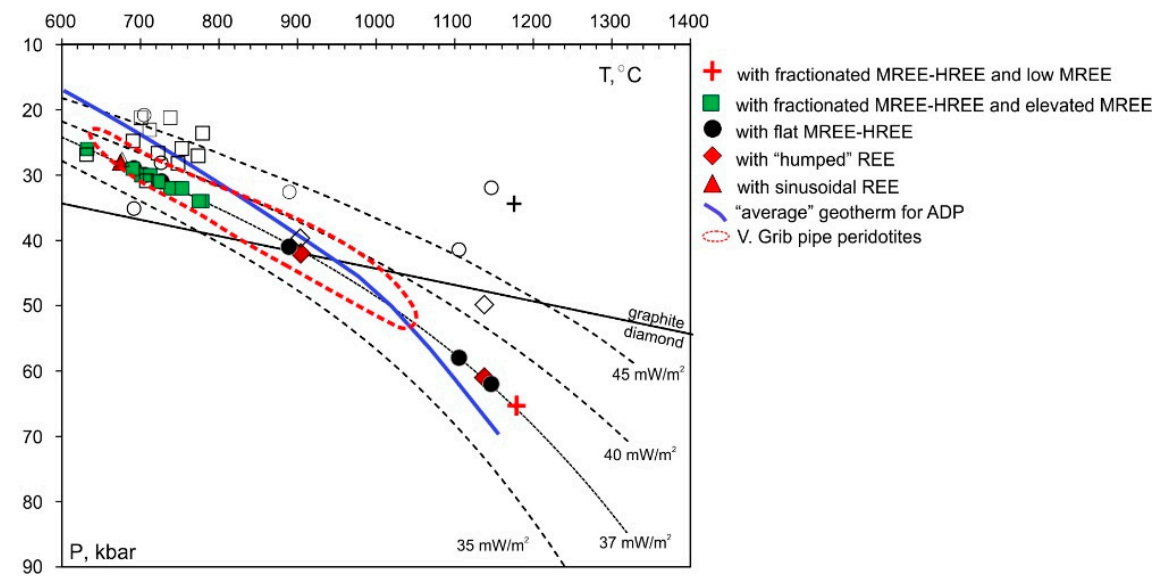

Figure 15. P-T estimates for the KL-01 pipe xenocrysts. (A) Distribution of estimated temperature [35] for pyrope and Cr-spinel xenocrysts from the KL-01 pipe. Pyrope xenocrysts from the V. Grib kimberlite pipe pyropes [33]; pyropes and Cr-spinel xenocrysts from the Arkhangelskaya pipe [16]; Cr-spinel xenocrysts from the V. Grib kimberlite pipes (Tables S5-1 in Supplementary Material). (B) P-T estimates for pyrope xenocrysts from the KL-01 pipe. Colored symbols-projecting of T values [35] onto $37 \mathrm{~mW} / \mathrm{m}^{2}$ geotherm; black-white symbols-P-T values obtained using the method of [35]. V. Grib pipe peridotites [32]; "average" geotherm for ADP [64]. Geotherms from [65].

7.3.2. Composition and Metasomatic Evolution of the Lithospheric Mantle Sampled by the KL-01 Pipe

The garnet compositions indicate at least two types of mantle rocks composed of lithospheric mantle: predominant $(78 \%)$ peridotites and subordinate $(22 \%)$ eclogites. All the peridotite garnets are of lherzolite paragenesis, and eclogite garnets could be from 
the high-MgO and low-MgO eclogite suite. The data on trace element compositions of lherzolite pyropes can provide some information about the metasomatic evolution of the lithospheric mantle and its suitability for the formation and preservation of diamonds.

Most lherzolite pyropes ( $57 \%$ of the total lherzolitic pyrope population) are low in chromium $\left(\mathrm{Cr}_{2} \mathrm{O}_{3}<4 \mathrm{wt}\right.$.\%) with fractionated patterns from MREEs to HREEs. One pyrope grain $(5 \%)$ of this group has a strong positive slope from LREEs to HREEs with MREEs near the $\mathrm{C} 1$ chondrite values and low $\mathrm{Y}, \mathrm{Zr}$ and $\mathrm{TiO}_{2}$ contents. Such pyropes have been previously observed in the V. Grib pipe lherzolites and xenocrysts [32,33], the Mir kimberlite pipe (Siberian craton) xenocrysts [34], as inclusions in diamonds from the Victor mine (Canada, VMG327-1 pyrope in [37]) and as exsolved pyropes in a Jagersfontein kimberlite (Kaapvaal craton) orthopyroxene megacryst (BD3736 in [38]; Figure 10A). This type of garnet matches the pre-metasomatic mantle garnet composition and could be "depleted". The P-T calculations indicate the origin of the pyrope from the lower depths $(\sim 180-190 \mathrm{~km})$ of the lithospheric mantle. The other pyropes of this group (11 grains; $52 \%$ ) have high MREE contents, mostly accompanied by positive correlations between $\mathrm{TiO}_{2}, \mathrm{Y}, \mathrm{Zr}$ and Sm. This type of pyrope has previously been found in lherzolites from the Premier pipe (Kaapvaal craton; PR90-57 in [40]), as websteritic garnet inclusions in diamonds from Jagersfontein (JF 122 in [39]) and in samples of modern rivers and stream sediments within the northern areas of the Arkhangelsk region ([3]; Figure 10B). The composition of such pyropes can reflect the early stage of metasomatic evolution of depleted pyropes. The compositions $\left(\mathrm{TiO}_{2}<0.06\right.$ wt.\%; $\mathrm{Y} / \mathrm{Zr}=2.6$ and 3.4) of two grains (nos. 10 and 16) exclude the influence of high-temperature silicate mantle melts, whereas other grains $\left(\mathrm{TiO}_{2}=0.09-0.2 \mathrm{wt} . \% ; \mathrm{Y} / \mathrm{Zr}\right.$ $=0.7-1.6)$ have signs of such influence. All of these pyropes could have originated from the shallow depths of the lithospheric mantle at $60-100 \mathrm{~km}$.

Low- to moderate-chromium pyropes with flat patterns from MREEs to HREEs are also a large population in the KL-01 pyrope samples (6 grains; $29 \%$ ). Such pyropes are most common within peridotite xenoliths from kimberlite localities worldwide; they are in major and trace element equilibrium with coexisting clinopyroxenes [66]. These pyropes show progressive increases in $\mathrm{Y}$ and $\mathrm{Zr}$, corresponding to high-temperature metasomatic trends [36], and the metasomatic agent could have had a silicate composition, most likely a basaltic composition in terms of trace elements $[32,33,66,67]$. According to P-T estimates, this type of mantle metasomatism could have occurred through all sections of the lithospheric mantle beneath the KL-01 pipe from 60 to $>150 \mathrm{~km}$.

Two pyrope grains (9\%) are high in chromium, have humped REE patterns and showing high $\mathrm{TiO}_{2}, \mathrm{Zr}$ and $\mathrm{Y}$ contents. Such pyropes are also frequently found in lherzolite xenoliths worldwide [68,69], including the ADP Arkhangelskaya and V. Grib kimberlite pipes $[16,32,33]$. No clinopyroxene shows trace element equilibrium with such garnet in peridotites [70]. The enrichments in HREEs in the pyropes indicate the silicate composition of the metasomatic agent. For the V. Grib peridotites, the composition of the parental melt for pyropes with humped REE patterns is concluded to be close to that of picrite [32,33], whereas for the Udachnaya peridotites, the parental melt composition was close to that of kimberlite $[67,70]$. The P-T calculations indicate the origin of the pyropes from the middle $(\sim 120 \mathrm{~km})$ and lower depths (>150 km) of the lithospheric mantle beneath the KL-01 pipe.

One pyrope grain (5\%) is low in $\mathrm{Cr}_{2} \mathrm{O}_{3}, \mathrm{TiO}_{2}, \mathrm{Y}$ and $\mathrm{Zr}$ and has a nearly sinusoidal REE pattern. To the best of my knowledge, this type of pyrope is not widespread within mantle peridotites in kimberlites worldwide but is abundant in samples of modern river and stream sediments within the northern areas of the Arkhangelsk region [3]. These pyropes could have been formed by the incursion of melts/fluids with high LREE/HREE ratios (carbonatite melt; [71,72]) into an initial low-chromium harzburgitic source [3] or by the reaction of the same melts/fluids with exsolved pyropes [33]. The P-T estimates indicate the origin of the pyrope to be from shallow depths in the lithospheric mantle $(60-90 \mathrm{~km})$.

The pyrope compositions indicate several types of metasomatic enrichment of the lithospheric mantle beneath the KL-01 pipe similar to those beneath diamondiferous localities, e.g., the ADP and the Siberian craton. The lower part $(>150 \mathrm{~km})$ of the lithospheric 
mantle has been affected at least by high-temperature silicate melts, nevertheless preserving lherzolites with depleted pyropes. The shallow part $(<150 \mathrm{~km})$ of the lithospheric mantle has been intensely metasomatized by both silicate and carbonatite types of metasomatism. In summary, the pyrope geochemistry shows that part of the lithosphere falls in the diamond stability field and has depleted and metasomatized signatures typically found in pyrope inclusions in diamonds. This suggests that the lithospheric mantle beneath the KL-01 pipe could be suitable for the formation and preservation of diamonds.

\section{Conclusions}

The compositions of sandstones in the KL-01 pipe clearly differ from those of the Vendian and Carboniferous Urzuga sandstones and show evidence of an admixture of magmatic material. According to the proposed model of binary mixing between the compositions of Vendian sandstones and typical ADP magmatic rocks, the type of magmatic component can be identified as kimberlite with a maximum of $20 \mathrm{vol}$ \% admixture in the BRH-2 samples at depths ranging from 140-150 m. The widespread distribution of montmorillonite in the KL-01 pipe sandstones can indicate that these sandstones may be predominantly a component from the upper level of the kimberlite pipe crater and that the lower boundary of the crater may be deeper than $300 \mathrm{~m}$ from the surface, with a thickness of at least $160 \mathrm{~m}$.

The major element compositions of the KL-01 pipe KIMs match those from the ADP kimberlites, with the following features: olivine and $\mathrm{Cr}$-diopside match those of the Lomonosov and Grib peridotites; Cr-spinel is similar to those from the Arkhangelskaya and V. Grib kimberlite pipes and Izhmozero melilitites/picrites; and Mg-ilmenite has affinities to those from the Tsnigri-Arkhangelskaya and Arkhangelskaya kimberlite pipes.

The garnet compositions indicate that at least two types of mantle rocks composed the lithospheric mantle beneath the KL-01 pipe-predominant peridotites and subordinate eclogites. The lower boundary of the sampled lithospheric mantle could be in the depth range of $175-190 \mathrm{~km}$ with a diamond window width of $55-70 \mathrm{~km}$. The pyrope geochemistry shows that part of the lithosphere falls in the diamond stability field and has depleted and metasomatized signatures which are typically found in pyrope inclusions in diamonds. This suggests that the lithospheric mantle beneath the KL-01 pipe could be suitable for the formation and preservation of diamonds. This study shows that the areas near boreholes 1 and 2 in the KL-01 pipe deserve more detailed drilling due to the high probability of discovering a new diamondiferous kimberlite pipe within the ADP.

The step-by-step use of the proposed model of binary mixing between the compositions of the Vendian sandstones and those of known ADP magmatic rocks can be applied to verify drilling of the prospective targets in the ADP territory to identify the type of magmatic material in the sandstones and exclude the sampling of the Carboniferous Urzuga suite, which will undoubtedly help in prospecting work for new kimberlite pipes in the region.

Supplementary Materials: The following are available online at https:/ /www.mdpi.com/2075-163 X/11/4/339/s1, Table S1: General information about ADP magmatic rocks; Table S2: Major (wt.\%) and trace (ppm) element composition of ADP magmatic rocks; Table S3: Major (wt.\%) and trace (ppm) element composition of sandstones from the crater parts of the ADP magmatic pipes and Vendian sandstones; Table S4: Major (wt.\%) and trace (ppm) element composition of kimberlite indicator minerals from the KL-01 pipe; Table S5: Major (wt.\%) element composition of Cr-spinel and Mg-ilmenite xenocrysts from the V. Grib and Tsnigri-Arkhangelskaya kimberlite pipes; Table S6: Average major (wt.\%) and trace (ppm) element composition of the ADP magmatic rocks used for modeling; Figure S1: Variety of the ADP pipe shapes in plan view and areal extent at the erosional surface; Figure S2: Schematic sections of the typical ADP magmatic pipes; Figure S3: Ca-Fe-Mg (mol.\%) diagram for garnet; Figure S4: Position of the KL-01 pipe olivines on the $\mathrm{Cr}_{2} \mathrm{O}_{3}-\mathrm{FeO}$ diagram; Figure S5: Major element composition of Cr-diopside xenocrysts from the KL-01 pipe.

Funding: This work was supported by the Russian Science Foundation Grant Numbers 17-77-10008 and 20-77-100018 to EA. The fieldwork and sampling were done on state assignment of IGM SB RAS.

Data Availability Statement: Not applicable. 
Acknowledgments: I am very grateful to the ex-chief geologist of the "Arkhangelskgeoldobycha", N.N. Golovin, for providing samples of the ADP magmatic pipes, and the head of the "Proex Service", V.S. Shchukin, for the possibility of conducting fieldwork within the "K" area of the ADP. This manuscript has benefited from the helpful comments of two anonymous reviewers.

Conflicts of Interest: The author declares no conflict of interest. The funders had no role in the design of the study; in the collection, analyses, or interpretation of data; in the writing of the manuscript, or in the decision to publish the results.

\section{References}

1. Shchukina, E.V.; Shchukin, V.S. Diamond exploration potential of the northern East European Platform. Minerals 2018, 8, 189. [CrossRef]

2. Smit, K.V.; Shor, R. Geology and development of the Lomonosov diamond deposit, Northwestern Russia. Gems Gemol. 2017, 53, 144-167. [CrossRef]

3. Shchukina, E.V.; Agashev, A.M.; Shchukin, V.S. Diamond-bearing root beneath the northern East European Platform (Arkhangelsk region, Russia): Evidence from Cr-pyrope trace-element geochemistry. Minerals 2019, 9, 261. [CrossRef]

4. Verichev, E.M. Geological Conditions of Formation and Exploration of the V. Grib Deposit. Ph.D Thesis, M.V. Lomonosov Moscow State University, Moscow, Russia, 2002. (In Russian).

5. Korotkov, Y.V. Search for Hidden Kimberlite Bodies Using Pulsed Inductive Electrical Prospecting in the Arkhangelsk Diamondiferous Province. Ph.D Thesis, Arkhangelsk Institute of Ecological Problems of the North, Arkhangelsk, Russia, 2012 (In Russian).

6. Stogniy, V.V.; Korotkov, Y.V. Search for Kimberlite Bodies by the Method of Transitional Processes; Publishing House "Small Circulation Printing 2D": Novosibirsk, Russia, 2010; p. 121. (In Russian)

7. Zinchuk, N.N. Specific features of typical models of kimberlite pipes and their use in diamond prospecting. Vestn. Voronezh State Univ. 2011, 1, 133-144. (In Russian)

8. Shevchenko, S.S.; Lokhov, K.I.; Sergeev, S.A. Isotope studies in VSEGEI. Prospects of application of results for predicting and search of diamond deposits. In Proceedings of the Scientific Practical Conference on Efficiency of Prediction and Search for Diamond Deposits: Past, Present, and Future, Saint-Petersburg, Russia, 25-27 May 2004; pp. 383-387.

9. Bogatikov, O.A.; Garanin, V.K.; Kononova, V.A.; Kudryavceva, G.P.; Vasil'eva, E.R.; Verzhak, V.V.; Verichev, E.M.; Parsadanyan, K.S.; Posuhova, T.V. Arkhangelsk Diamondiferous Province; Moscow State University: Moscow, Russia, 1999; p. 521, (In Russian). ISBN 5-211-02558-X.

10. Golovin, N.N. Geological Structure, Mineral Composition and Formation Conditions of Alkaline-Ultra-Basic Rocks of the Kepino Field (Arkhangelsk Diamondiferous Province). Ph.D Thesis, M.V. Lomonosov Moscow State University, Moscow, Russia, 2003. (In Russian).

11. Garanin, K.V. Alkaline Ultramafic Magmatites of the Zimny Bereg: Their Potential Diamond Content and Prospects for Industrial Development. Ph.D Thesis, M.V. Lomonosov Moscow State University, Moscow, Russia, 2004. (In Russian).

12. Shpilyaeva, D.V. Geological Structure, Mineral Composition, and Environmental Aspects of the Development of the Arkhangelskaya Pipe (the M.V. Lomonosov Diamond Deposit). Ph.D. Thesis, M.V. Lomonosov Moscow State University, Moscow, Russia, 2008. (In Russian).

13. Bogatikov, O.A.; Kononova, V.A.; Nosova, A.A.; Kondrashov, I.A. Kimberlites and lamproites of the East-European Platform: Petrology and geochemistry. Petrology 2007, 15, 315-334. [CrossRef]

14. Kononova, V.A.; Golubeva, Y.Y.; Bogatikov, O.A.; Kargin, A.V. Diamond resource potential of kimberlites from the Zimny Bereg field, Arkhangel'sk oblast. Geol. Ore Deposit. 2007, 49, 421-441. [CrossRef]

15. Smith, C.B.; Gurney, J.J.; Skinner, E.M.W.; Clement, C.R.; Ebrahim, N. Geochemical character of Southern African kimberlites: A new approach on isotopic constraints. Trans. Geol. Soc. S. Afr. 1985, 88, 267-280.

16. Lehtonen, M.; O’Brien, H.; Peltonen, P.; Kukkonen, I.; Ustinov, V.; Verzhak, V. Mantle xenocrysts from the Arkhangelskaya kimberlite (Lomonosov mine, NW Russia): Constraints on the composition and thermal state of the diamondiferous lithospheric mantle. Lithos 2009, 112, 924-933. [CrossRef]

17. Beard, A.D.; Downes, H.; Hegner, E.; Sablukov, S.M. Geochemistry and mineralogy of kimberlites from the Arkhangelsk Region, NW Russia: Evidence for transitional kimberlite magma types. Lithos 2000, 51, 47-73. [CrossRef]

18. Sinitsin, A.; Ermolaeva, L.; Grib, V. The Arkhangelsk diamond-kimberlite province-A recent discovery in the north of the east European platform. In Proceedings of the 5th International Kimberlite Conference, Araxa, Brazil, 18 June-4 July 1991; Companhia de Pesquisa de Recursos Minerals: Rio de Janeiro, Brazil; pp. 27-33.

19. Mahotkin, I.L.; Gibson, S.A.; Thompson, R.N.; Zhuravlev, D.Z.; Zherdev, P.U. Late Devonian diamondiferous kimberlite and alkaline picrite (proto-kimberlite?) magmatism in the Arkhangelsk region, Russia. J. Petrol. 2000, 41, 201-227. [CrossRef]

20. Mahotkin, I.L.; Sablukov, S.M.; Zhuravlev, D.Z.; Zherdev, P.U. Geochemistry and Sr-Nd composition of kimberlites, melilitites and basalts from the Arkhangelsk region, Russia. Int. Kimberl. Conf. Ext. Abstr. 1995, 6, 342-344.

21. Golubev, Y.K.; Prusakova, N.A.; Golubeva, Y.Y. Kepino field kimberlites, Arkhangelsk region. Ores Met. 2010, 1, 38-44. (In Russian)

22. Nikolaeva, I.V.; Palesskii, S.V.; Koz'menko, O.A.; Anoshin, G.N. Analysis of geologic reference materials for REE and HFSE by inductively coupled plasma-mass spectrometry (ICP-MS). Geochem. Int. 2008, 46, 1016-1022. [CrossRef] 
23. Korolyuk, V.N.; Lavrent'ev, Y.G.; Usova, L.V.; Nigmatulina, E.N. JXA-8100 microanalyzer: Accuracy of analysis of rock-forming minerals. Russ. Geol. Geophys. 2008, 49, 165-168. [CrossRef]

24. Lavrent'ev, Y.G.; Korolyuk, V.N.; Usova, L.V.; Nigmatulina, E.N. Electron probe microanalysis of rock-forming minerals with a JXA-8100 electron probe microanalyzer. Russ. Geol. Geophys. 2015, 56, 1428-1436. [CrossRef]

25. Horn, L.; Hinton, R.W.; Jackson, S.E.; Longerich, H.P. Ultra-trace element analysis of NIST SRM 616 and 614 using laser ablation microprobe-inductively coupled plasma mass spectrometry (LAM-ICP-MS): A comparison with secondary ion mass spectrometry (SIMS). Geostand. Newslett. 1997, 21, 191-203. [CrossRef]

26. Whitney, D.L.; Evans, B.W. Abbreviations for names of rock-forming minerals. Am. Mineral. 2010, 95, 185-187. [CrossRef]

27. Golubeva, Y.Y.; Pervov, V.A.; Kononova, V.A. Petrogenesis of Autoliths from Kimberlitic Breccias in the V. Grib Pipe (Arkhangelsk District). Dokl. Earth Sci. 2006, 411, 1257-1262. [CrossRef]

28. Grütter, H.S.; Gurney, J.J.; Menzies, A.H.; Winter, F. An updated classification scheme for mantle-derived garnet, for use by diamond explorers. Lithos 2004, 77, 841-857. [CrossRef]

29. Shchukina, E.V.; Agashev, A.M.; Soloshenko, N.G.; Streletskaya, M.V.; Zedgenizov, D.A. Origin of V. Grib pipe eclogites (Arkhangelsk region, NW Russia): Geochemistry, $\mathrm{Sm}-\mathrm{Nd}$ and $\mathrm{Rb}-\mathrm{Sr}$ isotopes and relation to regional Precambrian tectonics. Mineral. Petrol. 2019, 113, 593-612. [CrossRef]

30. Sobolev, N.V.; Lavrentyev, Y.G.; Pokhilenko, N.P.; Usova, L.V. Chrome-rich garnets from the kimberlites of Yakutia and their parageneses. Contrib. Mineral. Petrol. 1973, 40, 39-52. [CrossRef]

31. McDonough, W.F.; Sun, S.S. The composition of the Earth. Chem. Geol. 1995, 120, 223-253. [CrossRef]

32. Shchukina, E.V.; Agashev, A.M.; Kostrovitsky, S.I.; Pokhilenko, N.P. Metasomatic processes in the lithospheric mantle beneath the V. Grib kimberlite pipe (Arkhangelsk diamondiferous province). Russ. Geol. Geophys. 2015, 56, 1701-1716. [CrossRef]

33. Shchukina, E.V.; Agashev, A.M.; Pokhilenko, N.P. Metasomatic origin of garnet xenocrysts from the V. Grib kimberlite pipe, Arkhangelsk region, NW Russia. Geosci. Front. 2017, 8, 641-651. [CrossRef]

34. Agashev, A.M.; Serov, I.V.; Tolstov, A.V.; Shchukina, E.V.; Ragozin, A.L.; Pokhilenko, N.P. New genetic classification of lithospheric mantle garnets. In Proceedings of the 5th Russian Scientific and Practical Conference "Efficiency of Geological Exploration for Diamonds: Prospects, Resource, Methodology and Innovative-Technological Aspects", Mirny, Russia, 29 May-1 June 2018; pp. 338-342. (In Russian).

35. Ryan, C.G.; Griffin, W.L.; Pearson, N.J. Garnet geotherms: A technique for derivation of P-T data from Cr-pyrope garnets. J. Geophys. Res. 1996, 101, 5611-5625. [CrossRef]

36. Griffin, W.L.; Shee, S.R.; Ryan, C.G.; Win, T.T.; Wyatt, B.A. Harzburgite to lherzolite and back again: Metasomatic processes in ultramafic xenoliths from the Wesselton kimberlite, Kimberly, South Africa. Contrib. Mineral. Petrol. 1999, 134, 232-250. [CrossRef]

37. Stachel, T.; Banas, A.; Aulbach, S.; Smit, K.V.; Wescott, P.; Chinn, I.L.; Julie Kong, J. The Victor Mine (Superior Craton, Canada): Neoproterozoic lherzolitic diamonds from a thermally-modified cratonic root. Mineral. Petrol. 2018, 112 (Suppl. 1), S325-S326. [CrossRef]

38. Gibson, S.A. On the nature and origin of garnet in high-refractory Archean lithospheric mantle: Constraints from the garnet exsolved in Kaapvaal craton orthopyroxene. Mineral. Mag. 2017, 81, 781-809. [CrossRef]

39. Tappert, R.; Stachel, T.; Harris, J.W.; Muehlenbachs, K.; Ludwig, T.; Brey, G.P. Diamonds from Jagersfontein (South Africa): Messengers from the sublithospheric mantle. Contrib. Mineral. Petrol. 2005, 150, 505-522. [CrossRef]

40. Gregoire, M.; Bell, D.R.; Le Roex, A.P. Garnet lherzolites from the Kaapvaal craton (South Africa): Trace element evidence for a metasomatic history. J. Petrol. 2003, 44, 629-657. [CrossRef]

41. Schulze, D.J. Origins of chromian and aluminous spinel macrocrysts from kimberlites in Southern Africa. Can. Mineral. 2001, 39, 361-376. [CrossRef]

42. Nowicki, T.E.; Moore, R.O.; Gurney, J.; Baumgartner, M.C. Diamonds and associated heavy minerals in kimberlite: A review of key concepts and applications. In Developments in Sedimentology; Elsevier: Amsterdam, The Netherlands, 2007; Volume 58, pp. 1235-1267.

43. Wyatt, B.A.; Baumgartner, M.; Anchar, E.; Grutter, H. Compositional classification of "kimberlitic" and "non-kimberlitic" ilmenite. Lithos 2004, 77, 819-840. [CrossRef]

44. Kargin, A.V.; Nosova, A.A.; Sazonova, L.V.; Peresetskaya, E.V.; Golubeva, Y.Y.; Lebedeva, N.M.; Tretyachenko, V.V.; Khvostikov, V.A.; Burmii, J.P. Ilmenite from the Arkhangelsk Diamond Province, Russia: Composition, Origin and Indicator of Diamondiferous Kimberlites. Petrology 2020, 28, 315-337. [CrossRef]

45. Sobolev, N.V.; Shvedenkov, G.Y.; Zinchuk, Koroluk, V.N. Nitrogen in chromite and olivine coexisting with diamond. Dokl. Acad. Nauk USSR 1989, 309, 697-701. (In Russian)

46. Sablukov, S.M.; Sablukova, L.I.; Shavyrina, M.V. Mantle xenoliths from the Zimnii Bereg kimberlite deposits of rounded diamonds, Arkhangelsk diamondiferous province. Petrologia 2000, 8, 518-548. (In Russian)

47. Sazonova, L.V.; Nosova, A.A.; Kargin, A.V.; Borisovskiy, S.E.; Tretyachenko, V.V.; Abazova, Z.M.; Griban, Y.G. Olivine from the Pionerskaya and V. Grib kimberlite pipes, Arkhangelsk diamond province, Russia: Types, composition, and origin. Petrology 2015, 23, 227-258. [CrossRef]

48. Malkovets, V.G.; Zedgenizov, D.A.; Sobolev, N.V.; Kuzmin, D.V.; Gibsher, A.A.; Shchukina, E.V.; Golovin, N.N.; Verichev, E.M.; Pokhilenko, N.P. Contents of trace elements in olivines from diamonds and peridotite xenoliths of the V. Grib kimberlite pipe (Arkhangel'sk diamondiferous province, Russia). Dokl. Earth Sci. 2011, 436, 219-223. [CrossRef] 
49. Ramsey, R.R.; Tompkins, L.A. The geology, heavy mineral concentrate mineralogy, and diamond prospectivity of Boa Esperanca and Cana Verde pipes, Corrego D'anta, Minas Gerais, Brazil. In Kimberlites, Related Rocks and Mantle Xenoliths; Meyer, H.O.A., Leonardos, O.H., Eds.; Companhia de Pesquisa de Recursos Minerais: Araxá, Brazil, 1991; pp. 329-345.

50. Nimis, P. Evaluation of diamond potential from the composition of peridotitic chromian diopside. Eur. J. Mineral. 1998, 10, 505-519. [CrossRef]

51. Nimis, P.; Taylor, W.R. Single clinopyroxene thermobarometry for garnet peridotites. Part I. Calibration and testing of a Cr-in-Cpx barometer and an enstatite-in-Cpx thermometer. Contrib. Mineral. Petrol. 2000, 139, 541-554. [CrossRef]

52. Ziberna, L.; Nimis, P.; Kuzmin, D.; Malkovets, V.G. Error sources in single-clinopyroxene thermobarometry and a mantle geotherm for the Novinka kimberlite, Yakutia. Am. Mineral. 2016, 101, 2222-2232. [CrossRef]

53. Morkel, J.; Vermaak, M.K.G. The role of swelling clay in kimberlite weathering. Miner. Process. Extr. Metall. 2006, 115, 150-154. [CrossRef]

54. Morkel, J.; Pistorius, P.C.; Vermaak, M.K.G. Cation exchange behaviour of kimberlite in solutions containing $\mathrm{Cu}^{2+}$ and $\mathrm{K}^{+}$. Miner. Eng. 2007, 20, 1145-1152. [CrossRef]

55. Sobolev, V.K. To Study the Kimberlites of the Southeastern White Sea, Develop and Implement Methods for Their Forecasting and Assessment; Territorial Regional Geological Fund; TSNIGRI: Moscow, Russia, 1988. (In Russian)

56. Zinchuk, N.N. Comparative characteristics of weathering crust composition of kimberlite rocks in the Siberian and East-European platforms. Russ. Geol. Geophys. 1992, 33, 99-109.

57. Shcherbakova, T.E. Typomorphic Characteristics of Kimberlite Minerals in Pipe Halos and Their Use in Prospecting for Diamond Deposits within the Zimniy Bereg. Ph.D. Thesis, Central Research Institute of Geological Prospecting for Base and Precious Metals, Moscow, Russia, 2005. (In Russian).

58. Afanasiev, V.P.; Zinchuk, N.N.; Pokhilenko, N.P. Exploration Mineralogy of Diamond; Sobolev, N.V., Mityukhin, S.I., Eds.; Academic Publishing House "Geo": Novosibirsk, Russia, 2010; (In Russian). ISBN 978-5-9747-0180-1.

59. Vasil'ev, I.D. Geological Structures Near the Arkhangelskaya Kimberlite Pipe and Their Use for Diamond Exploration within the Zimnii Bereg. Ph.D. Thesis, Sergo Ordzhonikidze Russian State University for Geological Prospecting, Moscow, Russia, 2010. (In Russian).

60. Sobolev, V.K.; Koldaev, S.M.; Kolod'ko, A.A.; Levin, V.I. Method of Searching for Areas of Kimberlite. Russian. Federation Patent No. 2062493 , 20 June 1996.

61. Giuliani, A.; Pearson, D.G.; Soltys, A.; Dalton, H.B.; Phillips, D.; Foley, S.F.; Lim, E.; Goemann, K.; Griffin, W.L.; Mitchell, R.H. Kimberlite genesis from a common carbonate-rich primary melt modified by lithospheric mantle assimilation. Sci. Adv. 2020, 6, eaaz0424. [CrossRef] [PubMed]

62. Soltys, A.; Giuliani, A.; Phillips, D. A new approach to reconstructing the composition and evolution of kimberlite melts: A case study of the archetypal Bultfontein kimberlite (Kimberley, South Africa). Lithos 2018, 304-307, 1-15. [CrossRef]

63. Kjarsgaard, B.A.; Pearson, D.G.; Tappe, S.; Nowell, G.M.; Dowall, D.P. Geochemistry of hypabyssal kimberlites from Lac de Gras, Canada: Comparisons to a global database and applications to the parent magma problem. Lithos 2009, 112, 236-248. [CrossRef]

64. Afanasiev, V.P.; Ashchepkov, I.V.; Verzhak, V.V.; O’Brien, H.O.; Palessky, S.V. PT conditions and trace element variations of picroilmenites and pyropes from placers and kimberlites in the Arkhangelsk region, NW Russia. J. Asian Earth Sci. 2013, 70-71, 45-63. [CrossRef]

65. Hasterok, D.; Chapman, D.S. Heat production and geotherms for the continental lithosphere. Earth Planet. Sci. Lett. 2011, 307, 59-70. [CrossRef]

66. Agashev, A.M.; Ionov, D.A.; Pokhilenko, N.P.; Golovin, A.V.; Cherepanova, Yu.; Sharygin, I.S. Metasomatism in the lithospheric mantle roots: Constraints from WR and minerals chemical composition of deformed peridotite xenoliths from the Udachnaya kimberlite pipe. Lithos 2013, 160-161, 201-215. [CrossRef]

67. Howarth, G.H.; Barry, P.H.; Pernet-Fisher, J.F.; Baziotis, I.P.; Pokhilenko, N.P.; Pokhilenko, L.N.; Bodnar, R.J.; Tayor, L.A.; Agashev, A.M. Superplume metasomatism: Evidence from Siberian mantle xenoliths. Lithos 2014, 184-187, 209-224. [CrossRef]

68. Stachel, T.; Aulbach, S.; Brey, G.P.; Harris, J.W.; Leost, I.; Tappert, R.; Viljoen, K.S. The trace element composition of silicate inclusions in diamonds: A review. Lithos 2004, 77, 1-19. [CrossRef]

69. Ziberna, L.; Nimis, P.; Zanetti, A.; Marzoli, A.; Sobolev, N.V. Metasomatic processes in the central Siberian cratonic mantle: Evidence from garnet xenocrysts from the Zagadochnaya kimberlite. J. Petrol. 2013, 54, 2379-2409. [CrossRef]

70. Doucet, L.S.; Ionov, D.A.; Golovin, A.V. The origin of coarse garnet peridotites in cratonic lithosphere: New data on xenoliths from the Udachnaya kimberlite, central Siberia. Contrib. Mineral. Petrol. 2013, 165, 1225-1242. [CrossRef]

71. Shu, Q.; Brey, G.P. Ancient mantle metasomatism recorded in subcalcic garnet xenocrysts: Temporal links between mantle metasomatism, diamond growth and crustal tectonomagmatism. Earth Planet. Sci. Lett. 2015, 418, 27-39. [CrossRef]

72. Chepurov, A.A.; Faryad, S.W.; Agashev, A.M.; Strnad, L.; Jedlicka, R.; Turkin, A.I.; Mihaljevic, M.; Lin, V.V. Experimental crystallization of a subcalcic Cr-rich pyrope in the presence of REE-bearing carbonatite. Chem. Geol. 2019, 509, 103-114. [CrossRef] 